Article

\title{
Adoption of Sustainable Supply Chain Management for Performance Improvement in the Construction Industry: A System Dynamics Approach
}

\author{
Maria Ghufran ${ }^{1}$, Khurram Iqbal Ahmad Khan ${ }^{1, * \mathbb{D}}$, Muhammad Jamaluddin Thaheem ${ }^{2} \mathbb{D}$, \\ Abdur Rehman Nasir ${ }^{1}$ (D) and Fahim Ullah ${ }^{3}$ (D) \\ 1 Department of Construction Engineering and Management, National University of Sciences and \\ Technology (NUST), Islamabad 44000, Pakistan; mghufran.cem17nit@student.nust.edu.pk (M.G.); \\ abdur.nasir@nit.nust.edu.pk (A.R.N.) \\ 2 Geelong Waterfront Campus, School of Architecture and Built Environment, Deakin University, \\ Geelong, VIC 3220, Australia; jamal.thaheem@deakin.edu.au \\ 3 Springfield Campus, School of Surveying and Built Environment, University of Southern Queensland, \\ Springfield Central, QLD 4300, Australia; fahim.ullah@usq.edu.au \\ * Correspondence: khurramiqbal@nit.nust.edu.pk
}

\section{check for} updates

Citation: Ghufran, M.; Khan, K.I.A.; Thaheem, M.J.; Nasir, A.R.; Ullah, F. Adoption of Sustainable Supply Chain Management for Performance Improvement in the Construction Industry: A System Dynamics Approach. Architecture 2021, 1 , 161-182. https://doi.org/ 10.3390/architecture1020012

Academic Editors: Avi Friedman and Fahim Ullah

Received: 24 October 2021

Accepted: 9 December 2021

Published: 14 December 2021

Publisher's Note: MDPI stays neutral with regard to jurisdictional claims in published maps and institutional affiliations.

Copyright: (c) 2021 by the authors Licensee MDPI, Basel, Switzerland. This article is an open access article distributed under the terms and conditions of the Creative Commons Attribution (CC BY) license (https:/ / creativecommons.org/licenses/by/ $4.0 /)$.

\begin{abstract}
Sustainable supply chain management (SSCM) involves the managing of information, materials, cash flows, and collaboration among enterprises along the supply chain, integrating sustainable development goals. This research paper aims to determine challenges in SSCM adoption and to address related complexity using the system dynamics (SD) approach utilizing modeling and simulation techniques. This research identified challenges from the literature using content analysis. Causality among these identified challenges was determined using interviews and questionnaire surveys that led to the development of a causal loop diagram (CLD), which was used in the development of the SD model. Among the 19 shortlisted variables, CLD had IV reinforcing and II balancing loops. Moreover, CLD was used to build an SD model with two stocks, and a new stock named 'project performance' was added to envisage the cumulative impact of all stocks. The model was simulated for five years, and the results predict that the lack of top management commitment and corporate social responsibility adversely affects project performance. This implies that there is a need to improve numerous factors, in particular corporate social responsibility and top management commitment, which would lead to the adoption of SSCM, thus leading to a performance improvement for the construction industry (CI). The model was validated using boundary adequacy, structure, and parametric verification tests, which showed that the developed model is logical and approximately replicates the industry's actual system. The research findings will help the CI practitioners to adopt sustainability principles in terms of the supply chain and will not only enhance productivity and performance but will also help in the minimization of delays, promote long-term relations, and reduce communication gaps and project complexities.
\end{abstract}

Keywords: causal loop diagram; developing economies; sustainable supply chain management; system dynamics; systems thinking

\section{Introduction}

Construction is the largest employment-generating industry in a country and plays a crucial role in its economy [1,2]. The foremost concern of the CI is the improvement of the social, economic, and environmental sustainability indicators [3,4]. This industry has to face challenges, which include low profit margin and continuous project budget and schedule overruns $[5,6]$. Other issues consist of fragmentation, lack of coordination and trust among various supply chain stakeholders $[7,8]$, use of traditional contracting methods, lack of environmental regulations, and the labor-intensive construction industry [9-11]. 
The supply chain consists of a series of interconnected entities that are engaged in a variety of different activities $[12,13]$ that yield value through upstream and downstream linkages in goods and services from suppliers to the best customer [14,15]. It encompasses all those entities and processes, which are involved in accomplishing a customer order [16]. More stakeholders are involved in the management of resources, information, and processes $[17,18]$. Sustainability has been an important issue for the CI. The triple bottom line (TBL) perspective of sustainability includes economic (profit, cash flows, income), environmental (natural resources, energy conservation, land use) and social (education, equity, well-being, quality of life) performance [19-21], which is customary to characterize sustainable development in supply chains [22-26]. However, current sustainability studies are fundamentally associated with the improvement of environmental issues, exclusively their interface with economic ones [27]. The social perspective on sustainability has been regarded as the least defined and weakest pillar of sustainability, despite being frequently quoted but rarely examined [28,29].

Most of the research in the SSCM area primarily enlightens the environmental perspective, in contrast to the social perspective of sustainability [30,31]. Studies that still are focusing on the social dimension pay their attention to a single aspect of the dimension and do not look at the broader view, where the human factor plays a crucial role in social sustainability [4]. The last few decades have seen the emergence of a modern SSCM concept [31]. Ahi and Searcy [32] define SSCM as the creation of coherent supply chains by integrating economic, environmental, and social concerns with the foremost inter-structural business processes designed to manage resources, knowledge, and capital efficiently to meet stakeholder requirements [33]. According to Galal and Moneim [10], research has been carried out on SSCM in developed countries, but there is a lack of research when it comes to developing countries. Social sustainability, which assists the vulnerable workers and helps suppliers in the development of persisting relationships [34-36], appears missing from the research radar [4,37-39]. Discussing the construction sector, especially, the constructor sector of developing countries, there is an absence of research on SSCM [15,40-42]. Some research focuses on green supply chain management (GSCM) but pays no attention to the social perspective having a major impact [43-48]. Incorporating the social aspect in the supply chain concept will lead towards more sustainable supply chains [48-52]. Most research concentrates on the traditional concept of sustainability, with no explicit focus on the social aspect [53-61]. Moreover, regarding adoption, no specific study has been conducted to address complexity from the perspective of the construction industry [62-67]. To bridge this gap, this study will address the challenges causing complexity in the adoption of SSCM for performance improvement in the construction industry.

There is a need for the adoption of SSCM in the construction sector that focuses on the social aspect in addition to the environmental and economic aspects [68,69]. Incorporating social aspects in the supply chain concept will lead towards more sustainable supply chains [39]. However, the adoption of SSCM is not a straightforward process and involves complexity in terms of its adoption at various levels in the supply chain. The SD approach is used to simplify complexity in the adoption of SSCM using a feedback mechanism [40]. SD modeling has been used for strategic planning and policy analysis [41-43]. Therefore, keeping this in mind, the purpose of this research is to address the challenges causing complexity in the adoption of SSCM using the SD approach, utilizing modeling and simulation techniques leading to performance improvement in the construction industry.

The paper's structure consists of the following sections. Firstly, the background and introduction of the study are presented. Secondly, the literature review section acquaints readers with SSCM, followed by the SD approach. Reviewing the literature also identified the challenges in the adoption of SSCM in developing countries. Thirdly, the process for conducting research is described, which articulates the process for the data collection, data analysis, development of CLD, and SD model. Fourthly, the collection and review of data illustrate how data are obtained and evaluated. Fifthly, the findings and outcomes are deliberated along with the development of the CLD and SD model. The paper is finalized 
by providing conclusions, recommendations, and directions for added research in the last section.

\section{Literature Review}

The CI is fragmented, having issues such as communication gaps, design and construction separation, and poor collaboration among various stakeholders [9,44]. Supply chain management (SCM) is an implicit approach for the effective management of the CI $[30,45]$. The supply chain of a corporation comprises merchants, external suppliers, and end users called customers [46-49].

SCM is to plan, implement, and control supply chain operations at their best level $[14,50,51,69]$ that targets building trust and association among supply chain partners [6,52,53]. Construction supply chain management (CSCM) helps in achieving integration among the supply chain stakeholders such as suppliers, designers, merchants, contractors, subcontractors, and customers $[45,54,55]$. Sustainability is a multi-dimensional concept [56], a relationship between social, environmental, and economic realities, with constraints that constantly alter [39,57]. The review highlights the importance of the SSCM and SD approach in addressing the complexity issues in terms of the adoption of SSCM.

\subsection{Sustainable Supply Chain Management (SSCM)}

SSCM is apprehended as the unification of sustainable development and supply chain management, whereby sustainable development is most often explained as incorporating environmental, social, and economic issues [58]. The systematic alignment and accomplishment of an organization's social, environmental, and economic goals and objectives through the strategic alignment of substantial inter-organizational business procedures are referred to as SSCM [37]. All members of a supply chain must adhere to environmental and social requirements to make it sustainable [59]. In sustainable supply chains, the participants need to meet environmental, economic, and social requirements to stay in the supply chain $[60,61]$.

Most of the associated research in the field of SSCM is chiefly concentrated on the environmental dimension, in contrast to the social dimension [24,62]. Social sustainability in supply chains is about social interactions [63] between the supply chain stakeholders [64,65]. As the CI is labor-intensive, hence, it develops a standard in social sustainability practices across supply chains $[10,66]$. Although different facets of human rights (e.g., child and forced labor, freedom of association, and discrimination) and business practice can be included in social sustainability, modeling initiatives have tended only to focus on some of the more specific and quantifiable social aspects [67]. During the past two decades, the published literature has highlighted health and safety, child labor, pressure from the competition, consumer requirements, and employee union pressures as a few key points whose consideration needs time [68]. The social dimension is regarded as the most vulnerable pillar of sustainable development [69]. Recently, much consideration has been given to the social dimension of sustainability, whereas the interaction between the environmental and the social dimension is still an important unexplored terrain [36,70-72].

The CI in developing countries is one of the most complex, fragmented, time-sensitive, and resource-intensive industries [73-75]. There is a need for the adoption of SSCM practices leading to performance improvement of the construction sector.

\subsection{System Dynamics: An Approach to Deal with Complexity}

The SD approach is used to address complexities in the adoption of SSCM using a feedback mechanism $[40,53,76]$. It is a beneficial methodology for the comprehensive evaluation of a complex system [77]. It is an iterative modeling process that incorporates the use of stocks, flows, feedback loops, table functions, and time delays [76]. An important feature of the SD approach is that it tracks and interprets a given system over a period, combining different theories philosophies and techniques that help in providing useful framing, understanding the behavior shown by the management system [77]. For the 
economic and social progress of a country, construction activities are an important index [1]. Recently, a remarkable growth has been seen in many developing countries in terms of the amount, size, and complexity of major projects. The SD approach is opted for a better understanding of organizational dynamics and to deal with all the complexities involved in any project [40].

\subsection{Identification of Challenges from Literature}

After a comprehensive literature review, challenges causing hindrance in the adoption of SSCM with a particular focus on social dimension in the CI were identified. In total, 30 research papers were reviewed for the identification of challenges. Data analysis revealed 82 challenges ( 58 social, 14 economical, 10 environmental) in the adoption of SSCM. The social sustainability challenges include human rights, fair labor practices, health, safety, wellness, diversity, equity, work-life balance, empowerment, and community engagement $[63,78,79]$. The environmental challenges include green investments, waste minimization, product quality, etc. [12,25]. The economic challenges include high costs for waste disposal, product price, and so [25,65]. The identified challenges from the literature were rated based on their normalized score obtained via content analysis, with the impact of each challenge (high, medium, low) being evaluated via a comprehensive review of the literature [78], as shown in Table 1. A quantitative number was assigned to each impact (high as 5, medium as 3 , and low as 1). The highest frequency impact was selected for each challenge. Equation (1) depicts the calculation of the literature score [78], where $\mathrm{N}$ is the total number of papers considered to identify the challenges, $\mathrm{A}$ is the maximum possible score, and frequency depicts the repetition of challenges in papers.

Table 1. Ranking of challenges via normalized literature score.

\begin{tabular}{|c|c|c|c|c|c|}
\hline Sr.\# & Challenges & Nature & $\begin{array}{l}\text { Normalized } \\
\text { Score }\end{array}$ & Rank & Source \\
\hline 1 & Lack of top management commitment & Social & 0.071 & 2 & {$[56,63,79-81]$} \\
\hline 2 & Lack of training and education & Social & 0.066 & 1 & {$[18,25,56,82,83]$} \\
\hline 3 & $\begin{array}{l}\text { Complexity to design, reuse, } \\
\text { recycle product }\end{array}$ & Environmental & 0.051 & 59 & {$[12,13,25,27,84,85]$} \\
\hline 4 & Financial constraints & Economic & 0.051 & 72 & {$[13,48,56,65,80,82,86]$} \\
\hline 5 & Supply chain configuration & Social & 0.041 & 7 & {$[12,18,65,87-89]$} \\
\hline 6 & Organizational culture & Social & 0.036 & 30 & {$[12,18,79,90,91]$} \\
\hline 7 & Health and safety & Social & 0.031 & 44 & {$[10,18,69,79,85]$} \\
\hline 8 & Lack of awareness & Social & 0.025 & 26 & {$[63,80,83,92,93]$} \\
\hline 9 & Company policies & Social & 0.025 & 31 & {$[13,80,84,86,87]$} \\
\hline 10 & Environmental performance & Environmental & 0.025 & 65 & {$[79,83,87,89,94]$} \\
\hline 11 & Lack of trust & Social & 0.020 & 20 & {$[56,81,82,89]$} \\
\hline 12 & $\begin{array}{l}\text { Less involvement in environmental related } \\
\text { programs and meetings }\end{array}$ & Environmental & 0.020 & 63 & {$[13,27,86,93]$} \\
\hline 13 & High cost for waste disposal & Economic & 0.020 & 69 & {$[13,25,86,92]$} \\
\hline 14 & Return on investment & Economic & 0.020 & 74 & {$[13,18,65,86]$} \\
\hline 15 & Suppliers' top management commitment & Social & 0.018 & 4 & {$[13,56,81,95]$} \\
\hline 16 & Lack of resource (human) & Social & 0.018 & 11 & {$[13,83,86,92]$} \\
\hline 17 & Lack of corporate social responsibility & Social & 0.015 & 18 & {$[13,86,93,96]$} \\
\hline 18 & Child labor and forced labor & Social & 0.015 & 46 & {$[18,87,91]$} \\
\hline 19 & Discrimination & Social & 0.015 & 47 & {$[87,91]$} \\
\hline 20 & Human rights & Social & 0.015 & 51 & {$[18,79,91]$} \\
\hline 21 & Stakeholder engagement & Social & 0.012 & 56 & {$[18,56,87,91,93]$} \\
\hline 22 & Lack of awareness about reverse logistics & Social & 0.010 & 17 & {$[13,56,79,86]$} \\
\hline 23 & Suppliers firm culture & Social & 0.010 & 5 & {$[65,83,84]$} \\
\hline 24 & Inadequate performance measurement & Social & 0.010 & 24 & {$[56,92]$} \\
\hline 25 & Vendor selection & Social & 0.010 & 29 & [93] \\
\hline 26 & Lack of strategic planning & Social & 0.010 & 34 & {$[80,87]$} \\
\hline 27 & Employment creation & Social & 0.010 & 54 & {$[10,91]$} \\
\hline 28 & Gender inequality & Social & 0.010 & 55 & {$[10,87]$} \\
\hline 29 & Green induced changes & Environmental & 0.010 & 60 & {$[27,65]$} \\
\hline
\end{tabular}


Table 1. Cont.

\begin{tabular}{|c|c|c|c|c|c|}
\hline Sr.\# & Challenges & Nature & $\begin{array}{l}\text { Normalized } \\
\text { Score }\end{array}$ & Rank & Source \\
\hline 30 & Product quality & Environmental & 0.010 & 61 & {$[80,94]$} \\
\hline 31 & Lack of effective environmental measures & Environmental & 0.010 & 62 & {$[13,86]$} \\
\hline 32 & $\begin{array}{l}\text { Lack of government support to adopt } \\
\text { environmental friendly policies }\end{array}$ & Environmental & 0.010 & 64 & {$[13,86]$} \\
\hline 33 & Product price & Economic & 0.010 & 75 & {$[65,93]$} \\
\hline 34 & Economic uncertainty & Economic & 0.010 & 7 & {$[48,92]$} \\
\hline 35 & Cost of third part certification & Economic & 0.010 & 79 & {$[64,95]$} \\
\hline 36 & Availability of funds & Economic & 0.010 & 81 & {$[48,63]$} \\
\hline 37 & Suppliers firm size & Social & 0.009 & 6 & {$[65,90]$} \\
\hline 38 & Lack of technical expertise & Social & 0.009 & 12 & {$[13,56,86]$} \\
\hline 39 & Lack of customer awareness & Social & 0.009 & 14 & {$[13,86]$} \\
\hline 40 & Disbelief about environmental benefits & Social & 0.009 & 16 & {$[13,96]$} \\
\hline 41 & Philanthropy & Social & 0.009 & 45 & {$[18,79,91]$} \\
\hline 42 & Labor practices & Social & 0.009 & 49 & {$[18,91,93]$} \\
\hline 43 & Maintaining environmental suppliers & Social & 0.006 & 10 & {$[13,86]$} \\
\hline 44 & Fear of failure & Social & 0.006 & 13 & {$[13,86]$} \\
\hline 45 & Perception of out of responsibility zone & Social & 0.006 & 15 & {$[13,86]$} \\
\hline 46 & Suppliers' human skills & Social & 0.005 & 3 & {$[65]$} \\
\hline 47 & Resistance to change & Social & 0.005 & 21 & [56] \\
\hline 48 & Unwillingness to share risks and rewards & Social & 0.005 & 22 & [56] \\
\hline 49 & Cross functional conflicts & Social & 0.005 & 23 & [56] \\
\hline 50 & Employee involvement & Social & 0.005 & 28 & [90] \\
\hline 51 & Resistance to change to reverse logistics & Social & 0.005 & 32 & [80] \\
\hline 52 & Low commitment of partners & Social & 0.005 & 35 & [81] \\
\hline 53 & Reliability of supply & Social & 0.005 & 39 & [81] \\
\hline 54 & Poverty & Social & 0.005 & 43 & [91] \\
\hline 55 & Wages & Social & 0.005 & 48 & [91] \\
\hline 56 & Unethical practices & Social & 0.005 & 50 & [91] \\
\hline 57 & Sustainable sourcing & Social & 0.005 & 52 & [91] \\
\hline 58 & Local sourcing & Social & 0.005 & 53 & [91] \\
\hline 59 & Collaboration with suppliers & Social & 0.005 & 57 & [27] \\
\hline 60 & Collaboration with customers & Social & 0.005 & 58 & [27] \\
\hline 61 & Usage of renewable materials & Environmental & 0.005 & 66 & [86] \\
\hline 62 & Waste minimization & Environmental & 0.005 & 67 & [18] \\
\hline 63 & Eco-efficiency & Environmental & 0.005 & 68 & [18] \\
\hline 64 & Eco-friendly packaging cost & Economic & 0.005 & 70 & [25] \\
\hline 65 & $\begin{array}{l}\text { Cost of sustainability and } \\
\text { economic conditions }\end{array}$ & Economic & 0.005 & 71 & {$[25]$} \\
\hline 66 & Green investments & Economic & 0.005 & 73 & [65] \\
\hline 67 & Non availability of bank loans & Economic & 0.005 & 76 & [92] \\
\hline 68 & Distribution of cost benefits & Economic & 0.005 & 80 & {$[64]$} \\
\hline 69 & Initial buyer and supplier investment & Economic & 0.005 & 82 & [92] \\
\hline 70 & $\begin{array}{l}\text { Lack of information sharing between } \\
\text { construction firms and suppliers }\end{array}$ & Social & 0.004 & 19 & {$[13,27,86,96]$} \\
\hline 71 & Poor supplier commitment & Social & 0.003 & 27 & {$[25,90]$} \\
\hline 72 & $\begin{array}{l}\text { Reluctance of the support of dealers, } \\
\text { distributors, and retailers }\end{array}$ & Social & 0.003 & 33 & {$[80]$} \\
\hline 73 & Closer links between demand and supply & Social & 0.003 & 37 & [81] \\
\hline 74 & $\begin{array}{l}\text { Problems in maintaining } \\
\text { environmental suppliers }\end{array}$ & Social & 0.003 & 38 & {$[83]$} \\
\hline 75 & Initial burden on suppliers & & 0.003 & 40 & [92] \\
\hline 76 & Lack of legitimacy & Social & 0.003 & 41 & [90] \\
\hline 77 & Supplier commitment & Social & 0.003 & 42 & [90] \\
\hline 78 & Cost concern hinders & Economic & 0.003 & 78 & [83] \\
\hline 79 & $\begin{array}{c}\text { Focal firms' previous sustainability } \\
\text { experiences }\end{array}$ & Social & 0.001 & 8 & {$[65]$} \\
\hline 80 & Suppliers' location & Social & 0.001 & 9 & [65] \\
\hline 81 & Suppliers lack resources & Social & 0.001 & 25 & {$[86,92]$} \\
\hline 82 & Frequent meetings & Social & 0.001 & 36 & [81] \\
\hline
\end{tabular}




$$
\text { Literature Score }=\text { Impact score } \times \frac{\text { Frequency }}{\mathrm{A} \times \mathrm{N}}
$$

The literature score was converted into the normalized score by dividing the individual literature score of each challenge by the sum of the literature score. The normalized score was then arranged in descending order and the cumulative score was calculated. This technique was used for the elimination of less significant factors [3].

\section{Method and Materials}

This study is conducted in IV phases as presented in Figure 1.

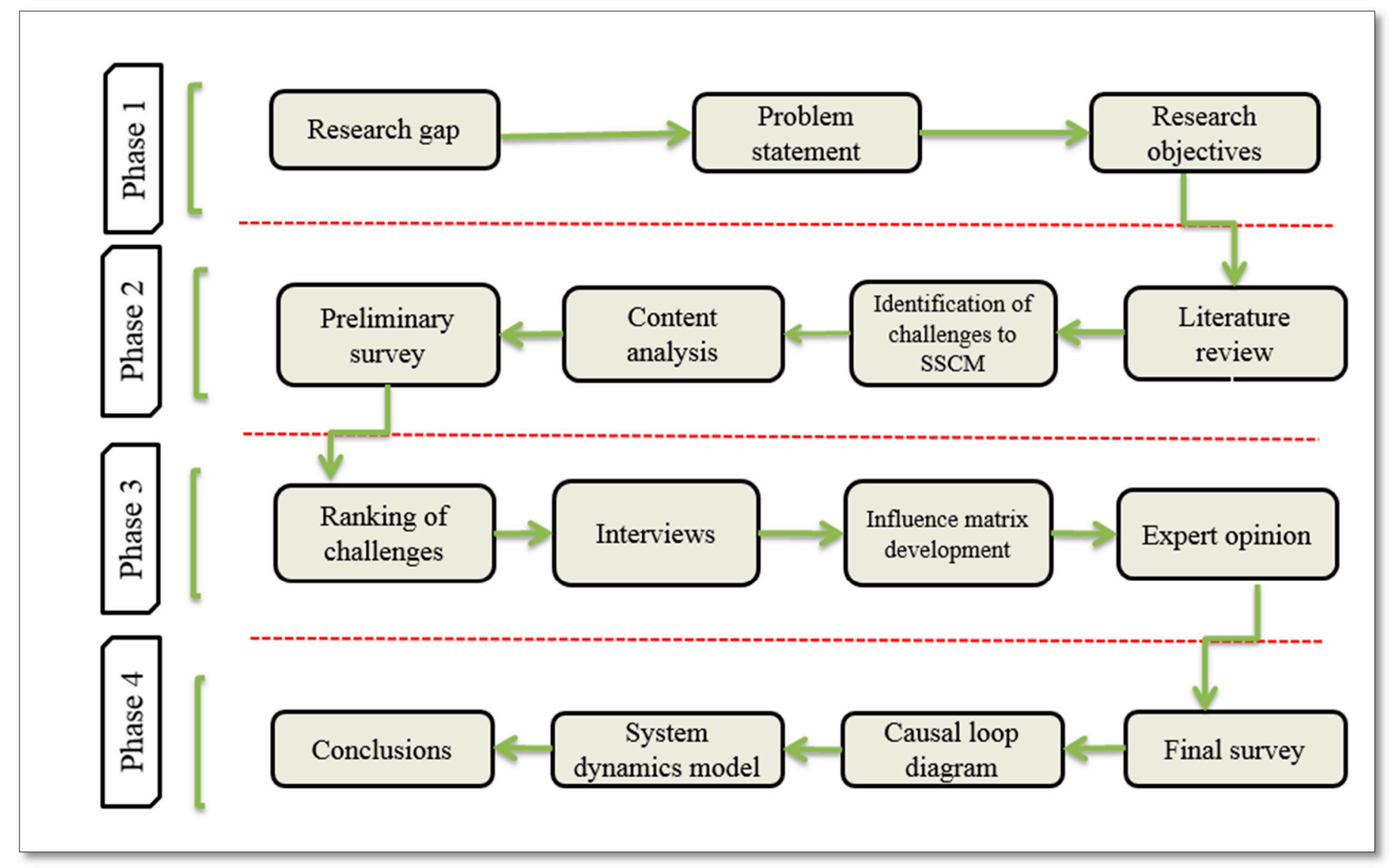

Figure 1. Methodology chart.

\subsection{Data Collection and Analysis}

The first phase involved the scrutiny of the literature in establishing the research gap, which helped in the development of the problem statement, followed by the identification of research objectives. In the second phase, data analysis revealed 82 challenges (58 social, 14 economical, 10 environmental) in the adoption of SSCM. A preliminary survey was conducted in which respondents were asked to rate the importance of each challenge on a scale of 1 (extremely low impact) to 5 (extremely high impact). The collective score from the field and literature data was used to determine the final ranking of challenges. The top 30 factors were shortlisted ( 20 social, 5 economical, 5 environmental). The response rate for this survey was 30 (in numbers). According to Chan [57], a sample size of 30 or above is generally accepted, so this data includes respondents from Brazil, Morocco, Bangladesh, Qatar, Maldives, and Pakistan. Based on the preliminary survey, the field score was also calculated and then normalized. 
A one-way ANOVA analysis was used to see if there were any statistically significant differences in values when evaluated through weighing ratios i.e., 40/60, 50/50, 30/70, etc. Obtaining a $p$-value of 1 between the combinations of different ratios proposed insignificant disparity. After ANOVA analysis, a 60/40 weighting distribution (60\% Field, $40 \%$ Literature) was adopted in the third phase, and PARETO analysis was used to shortlist the factors having a 50\% impact score $[78,97]$. The ranking of these factors along with the codes assigned is presented in Table 2 .

Table 2. Shortlisting of factors having 50\% impact.

\begin{tabular}{|c|c|c|c|c|c|}
\hline Code & Challenges & $60 \mathrm{R} / 40 \mathrm{~L}$ & Cumulative Score & Rank & Nature of Challenge \\
\hline $\mathrm{C} 1$ & Lack of top management commitment & 0.0346 & 0.0346 & 1 & Social \\
\hline $\mathrm{C} 2$ & Lack of training and education & 0.0346 & 0.0692 & 2 & Social \\
\hline $\mathrm{C} 26$ & $\begin{array}{l}\text { Complexity to design, reuse, } \\
\text { recycle product }\end{array}$ & 0.0285 & 0.0977 & 3 & Environmental \\
\hline $\mathrm{C} 21$ & Financial constraints & 0.0285 & 0.1261 & 4 & Economical \\
\hline $\mathrm{C} 3$ & Supply chain configuration & 0.0224 & 0.1485 & 5 & Social \\
\hline $\mathrm{C} 4$ & Organizational culture & 0.0203 & 0.1688 & 6 & Social \\
\hline C5 & Health and safety & 0.0183 & 0.1871 & 7 & Social \\
\hline C6 & Lack of awareness & 0.0183 & 0.2054 & 8 & Social \\
\hline $\mathrm{C} 7$ & Company policies & 0.0183 & 0.2237 & 9 & Social \\
\hline $\mathrm{C} 27$ & Environmental performance & 0.0163 & 0.2400 & 10 & Environmental \\
\hline $\mathrm{C} 8$ & Lack of trust & 0.0163 & 0.2562 & 11 & Social \\
\hline $\mathrm{C} 29$ & $\begin{array}{l}\text { Less involvement in environmental } \\
\text { related programs and meetings }\end{array}$ & 0.0163 & 0.2725 & 12 & Social \\
\hline $\mathrm{C} 23$ & High cost for waste disposal & 0.0163 & 0.2888 & 13 & Economical \\
\hline $\mathrm{C} 22$ & Return on investment & 0.0163 & 0.3050 & 14 & Economical \\
\hline C9 & Suppliers' top management commitment & 0.0154 & 0.3204 & 15 & Social \\
\hline $\mathrm{C} 10$ & Lack of resource (human) & 0.0154 & 0.3359 & 16 & Social \\
\hline C11 & Lack of corporate social responsibility & 0.0142 & 0.3501 & 17 & Social \\
\hline $\mathrm{C} 12$ & Child labor and forced labor & 0.0142 & 0.3643 & 18 & Social \\
\hline $\mathrm{C} 13$ & Stakeholder engagement & 0.0142 & 0.3785 & 19 & Social \\
\hline $\mathrm{C} 30$ & Product quality & 0.0142 & 0.3928 & 20 & Environmental \\
\hline $\mathrm{C} 14$ & Lack of awareness about reverse logistics & 0.0130 & 0.4057 & 21 & Social \\
\hline $\mathrm{C} 15$ & Discrimination & 0.0122 & 0.4179 & 22 & Social \\
\hline $\mathrm{C} 16$ & Human rights & 0.0122 & 0.4301 & 23 & Social \\
\hline $\mathrm{C} 17$ & Suppliers firm culture & 0.0122 & 0.4423 & 24 & Social \\
\hline $\mathrm{C} 20$ & Inadequate performance measurement & 0.0122 & 0.4545 & 25 & Social \\
\hline C19 & Lack of strategic planning & 0.0122 & 0.4667 & 26 & Social \\
\hline $\mathrm{C} 18$ & Gender inequality & 0.0122 & 0.4789 & 27 & Social \\
\hline $\mathrm{C} 28$ & $\begin{array}{l}\text { Lack of government support to adopt } \\
\text { environmental friendly policies }\end{array}$ & 0.0122 & 0.4910 & 28 & Environmental \\
\hline $\mathrm{C} 24$ & Product price & 0.0122 & 0.5032 & 29 & Economical \\
\hline $\mathrm{C} 25$ & Economic uncertainty & 0.0122 & 0.5154 & 30 & Economical \\
\hline
\end{tabular}

In this phase, interviews were conducted, in which industry professionals were asked about the existence of interrelationships among the identified challenges and, in addition, the polarity among these in phase 1 . This resulted in 95 relationships, which helped in the development of the influence matrix. These professionals were asked about the root cause of each challenge in phase 3 . A total of 24 relationships and 19 challenges (having interrelationships) were shortlisted that helped in the development of the CLD. A total of seven industry professionals were contacted in this phase. In this phase, expert opinion was acquired (for shortlisting interrelationships among challenges and determination of polarity) that helped in the development of the influence matrix shown in Figure 2. The value of 1 indicates that there is a positive relationship between the two challenges, whereas -1 indicates a negative relationship between them. 


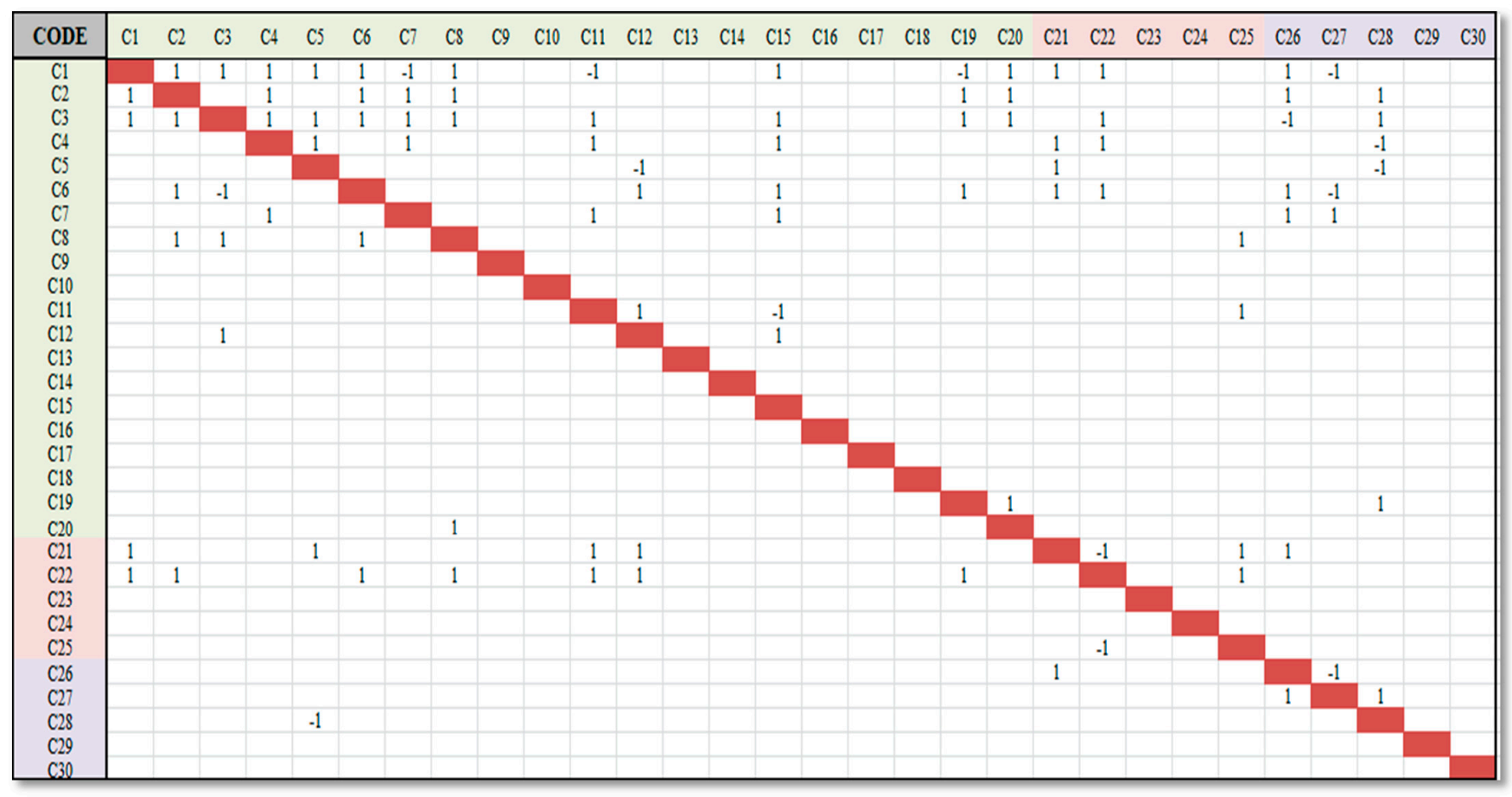

Figure 2. Influence matrix.

Based on 24 relationships, in the fourth phase, the next step was to determine the impact of one variable on another. This helped in the development of equations and functionalizing the SD model. This was accomplished using a bi-section questionnaire developed in Google ${ }^{\circledR}$ Docs [78]. The questions in the head section were about general information about the respondents, such as qualification, experience, job title, and so on. The second section is comprised of the Likert scale from 0 to 5 , where 0 shows no impact and 5 shows a very high impact. The questionnaire survey was distributed to respondents in various developing countries via email, and professional networks such as LinkedIn. Over 1500 scholars and field personnel were contacted, yielding a total of 125 responses. The central limit theorem is often satisfied when the sample size is 30 or greater [57]. After the data were collected, they were arranged, and the responses were tested for consistency and reliability using simple statistical tools. The Cronbach's coefficient alpha technique was used to assess the data's reliability and consistency. The minimum acceptable value for Cronbach's alpha is 0.7 [98]. The data collected had a Cronbach's alpha value of 0.97 , indicating that they were reliable and consistent.

\subsection{Survey Demographics}

The final survey demographic details are given in Table 3 and shown in Figures 3 and 4. A multitude of construction professionals were pursued, including construction managers, designers, site managers, assistant managers, and planning engineers, but the most responses were received from project managers $(18 \%)$. A total of 43 respondents had more than 10 years of construction experience, indicating that $35 \%$ of the responses came from experienced professionals. Organization-wise, a total of $68 \%$ of responses were obtained from private firms and $24 \%$ of responses were obtained from semi-government firms, as shown in Figure 3. M.Sc. holders accounted for $43 \%$ of responses, while Ph.D. holders accounted for $9 \%$, implying that highly skilled professionals accounted for $52 \%$ of all responses. BE graduates accounted for a respectable $42 \%$ of responses, although $\mathrm{B}$. Tech holders accounted for just $6 \%$ of total responses. Most respondents hold high qualifications, which validate their opinion's credibility. Information on awareness about SSCM is important in the $\mathrm{CI}$, and the findings reveal that more than $77 \%$ of respondents have a moderate to an exceptional understanding of SSCM. 
Table 3. Data Demographics.

\begin{tabular}{|c|c|c|}
\hline Profile & Frequency & Percentage \\
\hline \multicolumn{3}{|c|}{ Job Title } \\
\hline $\mathrm{CEO}$ & 5 & $4 \%$ \\
\hline Project Director & 6 & $5 \%$ \\
\hline Project Manager & 12 & $10 \%$ \\
\hline Construction Manager & 9 & $7 \%$ \\
\hline Assistant Manager & 12 & $10 \%$ \\
\hline Project manager & 22 & $18 \%$ \\
\hline Planning Engineer & 15 & $12 \%$ \\
\hline Site Manager & 4 & $3 \%$ \\
\hline Architect/Designer & 6 & $5 \%$ \\
\hline University Professor & 10 & $8 \%$ \\
\hline Other & 24 & $19 \%$ \\
\hline \multicolumn{3}{|c|}{ Years of Experience } \\
\hline $0-5$ & 55 & $44 \%$ \\
\hline $6-10$ & 27 & $22 \%$ \\
\hline $11-20$ & 21 & $17 \%$ \\
\hline$>20$ & 22 & $18 \%$ \\
\hline \multicolumn{3}{|c|}{ Qualification } \\
\hline Diploma Holder & 7 & $6 \%$ \\
\hline Graduate & 53 & $42 \%$ \\
\hline Post-Graduate & 54 & $43 \%$ \\
\hline $\mathrm{PhD}$ & 11 & $9 \%$ \\
\hline \multicolumn{3}{|c|}{ Understanding of SSCM } \\
\hline No understanding at all & 5 & $4 \%$ \\
\hline Slight & 24 & $19 \%$ \\
\hline Moderate & 77 & $62 \%$ \\
\hline Exceptional & 19 & $15 \%$ \\
\hline
\end{tabular}

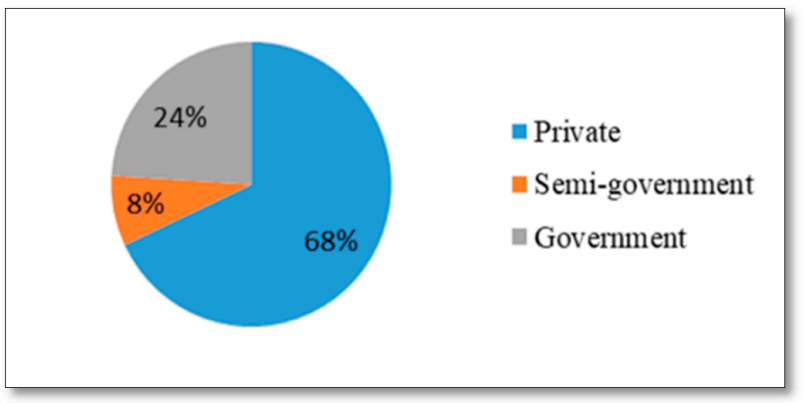

Figure 3. Organization type.

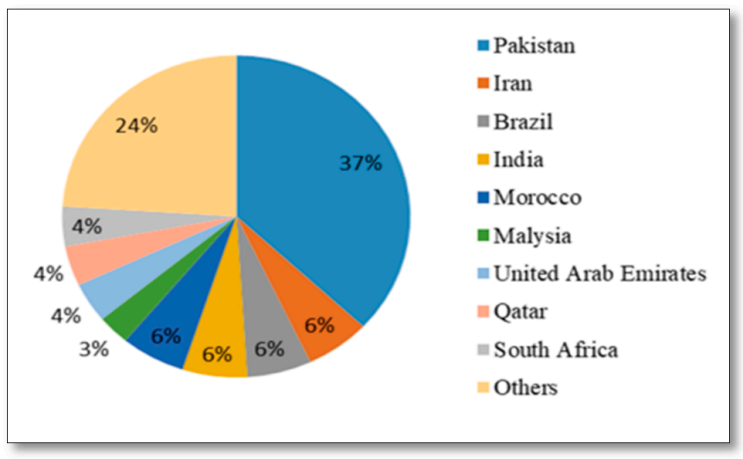

Figure 4. Regional distribution of respondents. 


\subsection{Regional Distribution of Responses}

A total of 125 responses were obtained from 20 countries, as displayed in Figure 4. Responses were received from countries including Pakistan (37\%), Brazil (6\%), India (6\%), Morocco (6\%), UAE (4\%), Qatar (4\%), South Africa (4\%), Malaysia (3\%), and from other developing countries $(24 \%)$. As the focus of the study was limited to developing countries, responses were received only from those countries.

\subsection{System Dynamics Approach}

A CLD is developed to determine the relationship among variables, balancing and reinforcing feedback loops in the holistic system $[40,99]$. In SD models, every pair of variables has a cause and effect, indicating that the variables can move in the same or opposite direction [100]. Polarities among links only predict what would happen if there is a change, they do not show the behavior of variables [101-104]. Tracing the variable's effects as they propagate around the loop determines polarity [40]. A reinforcing loop is represented by " $R$ ", which depicts actions that produce a result and then lead to more actions that produce more results in the identical direction, whereas a balancing loop is represented by "B", which generates the system's state in the opposite direction [104].

\section{Results and Discussions}

\subsection{Causal Loop Diagram}

The CLD was constructed based on interrelationships using VENSIM ${ }^{\circledR}$. To endorse its importance and applicability to the CI, the CLD was developed based on expert opinions from construction personnel with over $15+$ years of experience. The explanation of the CLD comprising of six loops, i.e., four reinforcing and two balancing, is given below:

\subsubsection{Reinforcing Loop R1}

Figure 5 shows if there is an increase in lack of top management commitment, there would be an increase in issues in the supply chain configuration leading to an increase in lack of training and education. This increase will lead to an increase in lack of awareness, which shows increased complexities to design, reuse, and recycle products that will lead to decreased environmental performance, showing an increase in the lack of government support for the adoption of environmentally friendly policies. This decrease would lead to an increase in health and safety issues, which leads to an increase in lack of top management commitment. Hence, this loop shows that lack of top management commitment reinforces various environmental and social challenges to SSCM adoption.

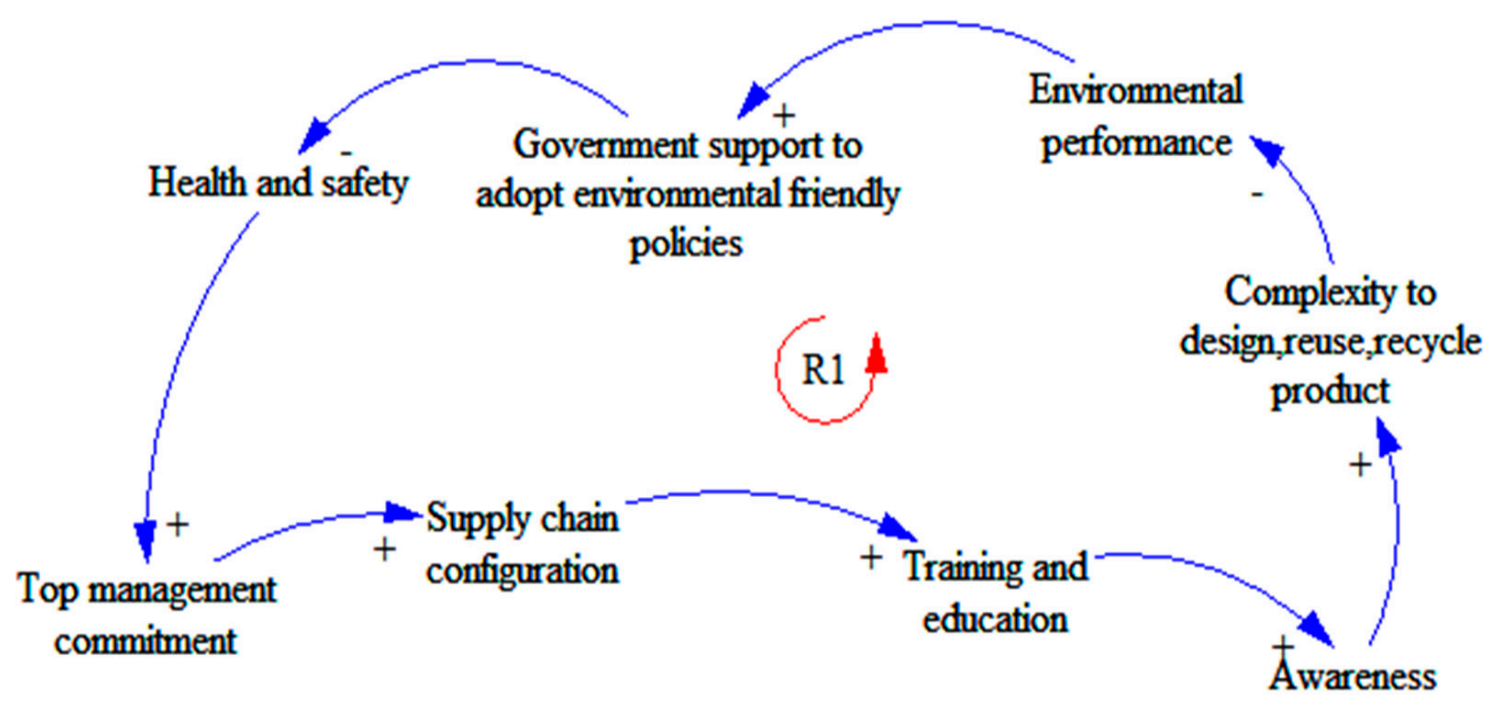

Figure 5. Reinforcing loop R1. 


\subsubsection{Reinforcing Loop R2}

Figure 6 shows if there is an increase in lack of top management commitment, there would be an increase in issues in the supply chain configuration leading to an increase in lack of training and education. This increase will lead to an increase in lack of awareness, which will lead to an increase in lack of strategic planning that leads to an increase in inadequate performance measurement, due to which there would be an increase in lack of trust. This increase will lead to an increase in the lack of top management commitment. Hence, this loop shows that lack of top management commitment reinforces various social challenges to SSCM adoption.

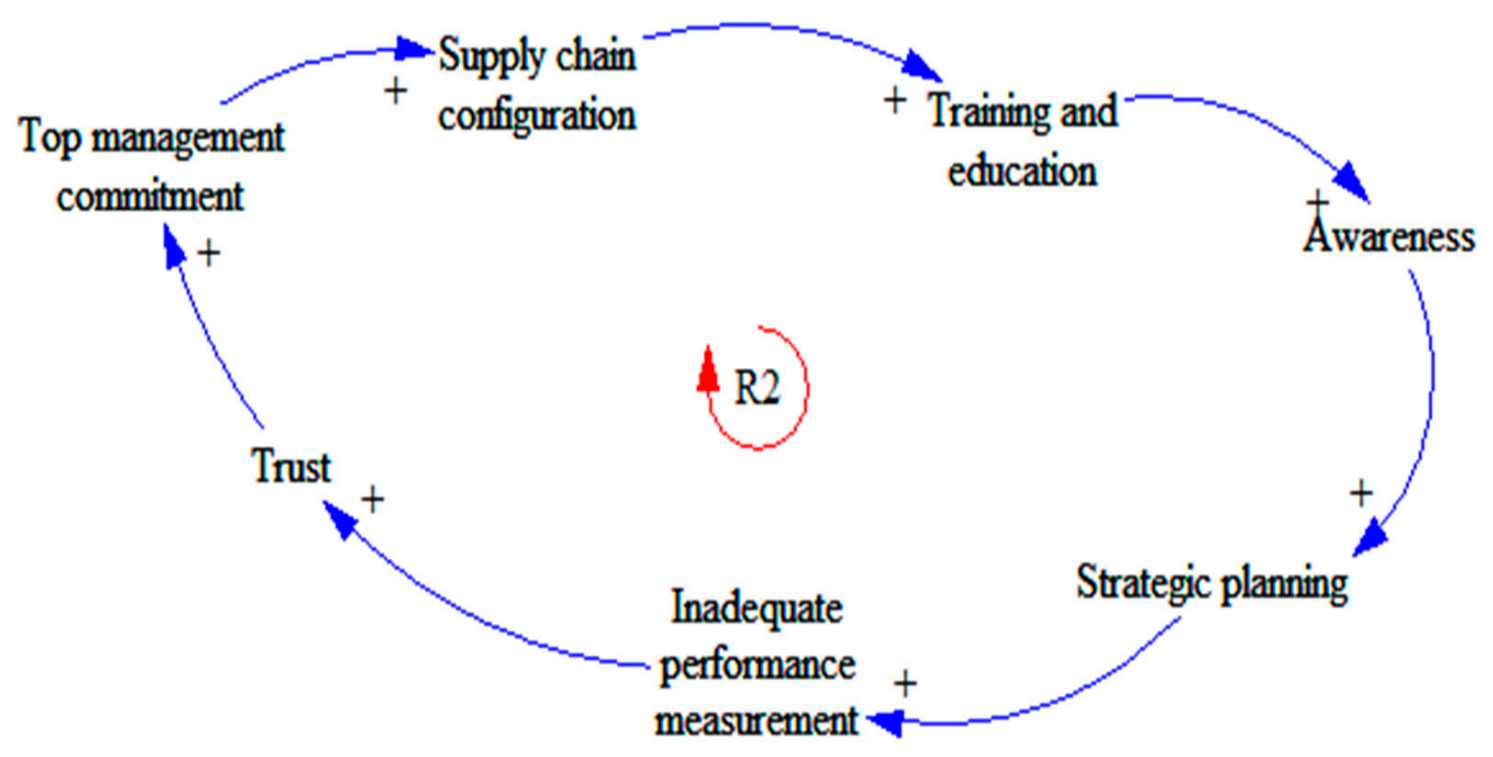

Figure 6. Reinforcing loop R2.

\subsubsection{Reinforcing Loop R3}

Figure 7 illustrates that an increase in lack of corporate social responsibility will lead to an increase in child labor and forced labor, which increases discrimination that again leads to an increase in lack of corporate social responsibility. Hence, this loop shows how the lack of corporate social responsibility can reinforce social issues such as child labor and discrimination.

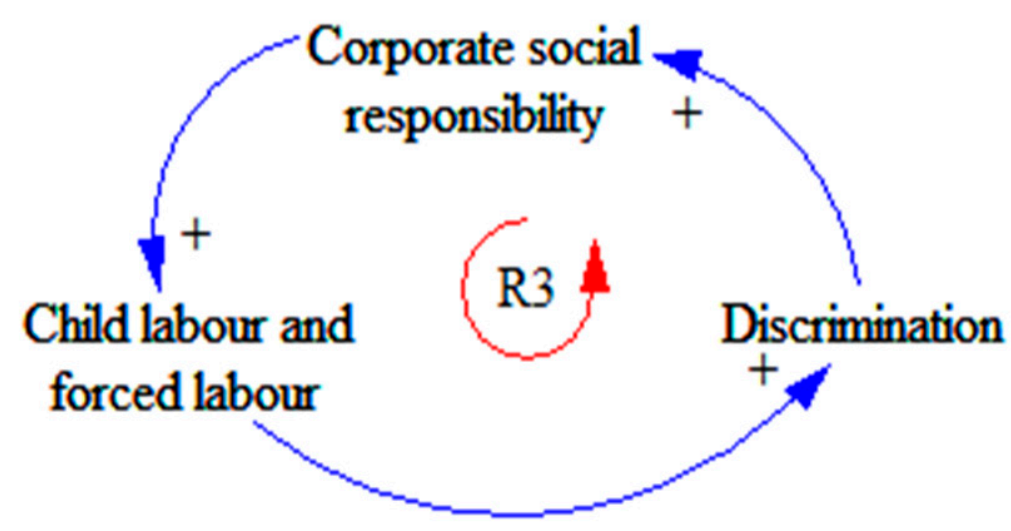

Figure 7. Reinforcing loop R3. 


\subsubsection{Reinforcing Loop R4}

An increase in lack of top management commitment leads to an increase in financial constraints, which lead to an increase in child labor and forced labor (as shown in Figure 8). This increase leads to an increase in discrimination that leads to an increase in lack of corporate social responsibility, which again leads to an increase in lack of top management commitment. This loop elaborates on how social and financial challenges to SSCM adoption reinforce each other.

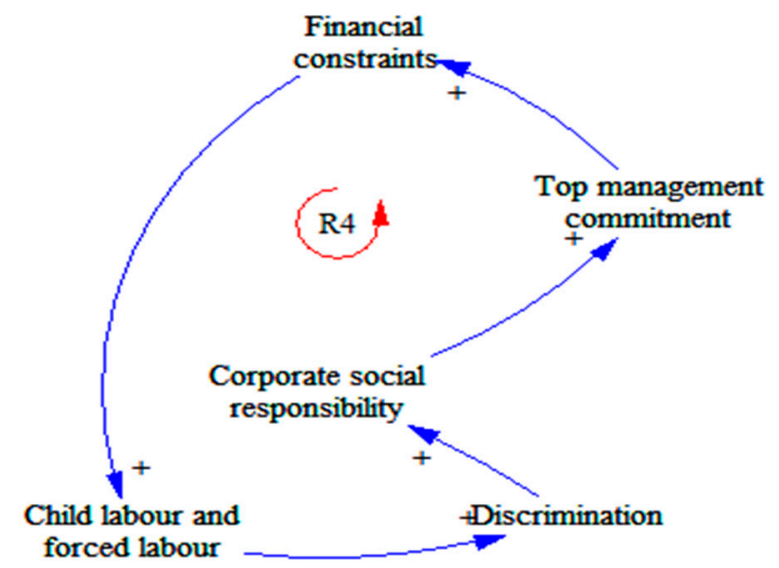

Figure 8. Reinforcing loop R4.

\subsubsection{Balancing Loop B1}

An increase in lack of top management commitment will lead to an increase in financial constraints, which promotes economic uncertainty (as shown in Figure 9). Increased economic uncertainty will lead to a decreased return on investment, which leads to an increase in lack of top management commitment. This loop elaborates the effect of top management commitment on economic challenges to SSCM adoption.

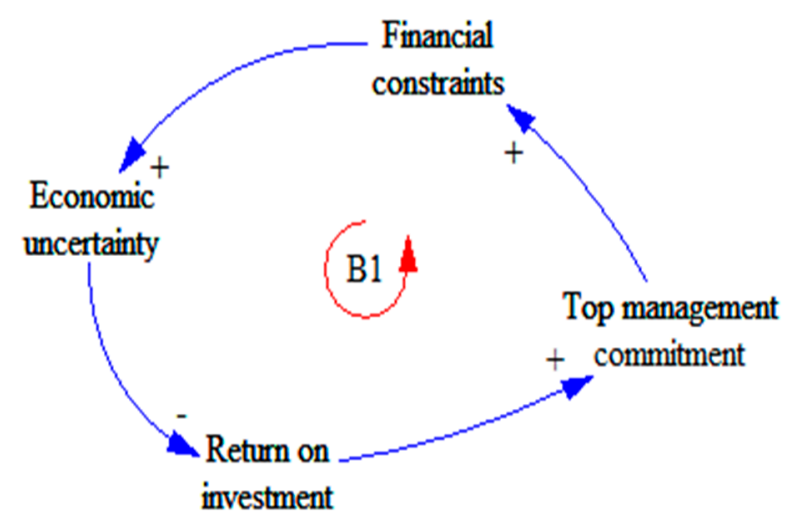

Figure 9. Balancing loop B1.

\subsubsection{Balancing Loop B2}

Considering balancing loop B2 (as shown in Figure 10), an increase in lack of top management commitment will lead to a decrease in company policies. This will lead to an increase in the deterioration of organizational culture, which leads to an increase in the lack of corporate social responsibility leading to an increase in lack of top management commitment. This loop explains the effect of social challenges on each other. 


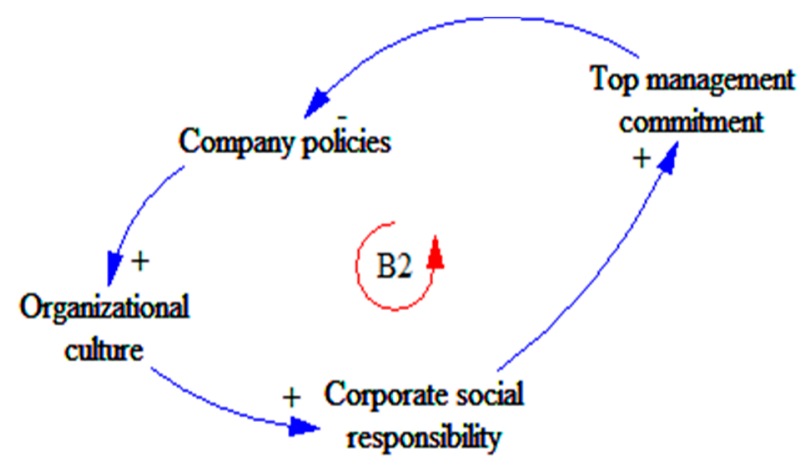

Figure 10. Balancing loop B2.

Figure 11 is a consolidated diagram of all loops. The CLD has been fed into the SD model.

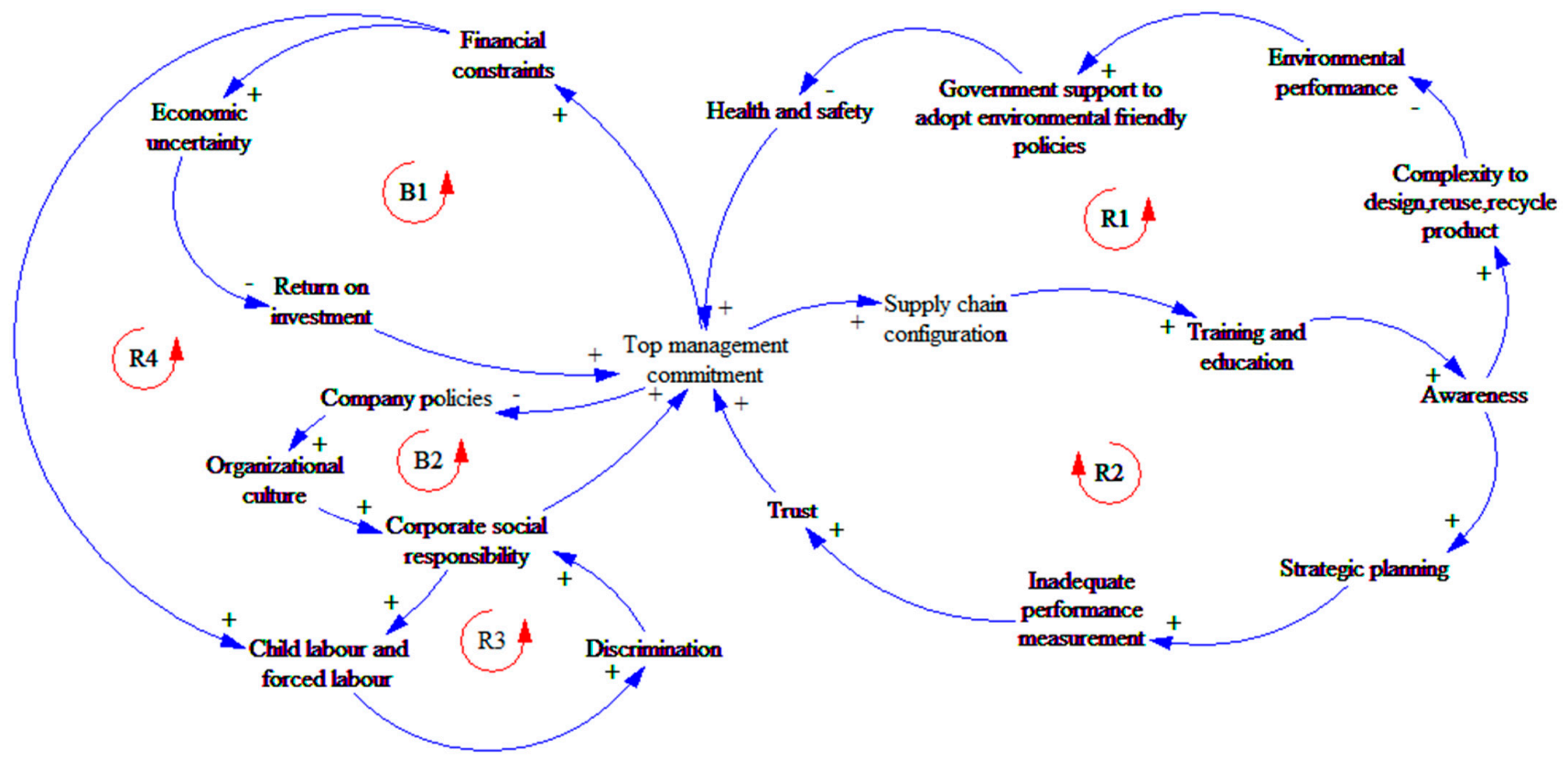

Figure 11. Feedback causal loop diagram.

\subsection{System Dynamics Model}

The SD model was generated from CLD using VENSIM ${ }^{\circledR}$ [105] shown in Figure 12 below. The model consists of three stocks, including "Top management commitment", "Corporate social responsibility", and "Project performance", governed by inflows and outflows. The top management commitment and corporate social responsibility were selected as stocks, as they were showing accumulation since these were the two challenges that were having most of the interrelationships with the other challenges. Thus, they are showing the combined effect of variables in connection with them, influencing the project performance, which is an additional stock created to represent the cumulative effect of all stocks. The data collected in the final survey also helped in the development of equations in the model. 


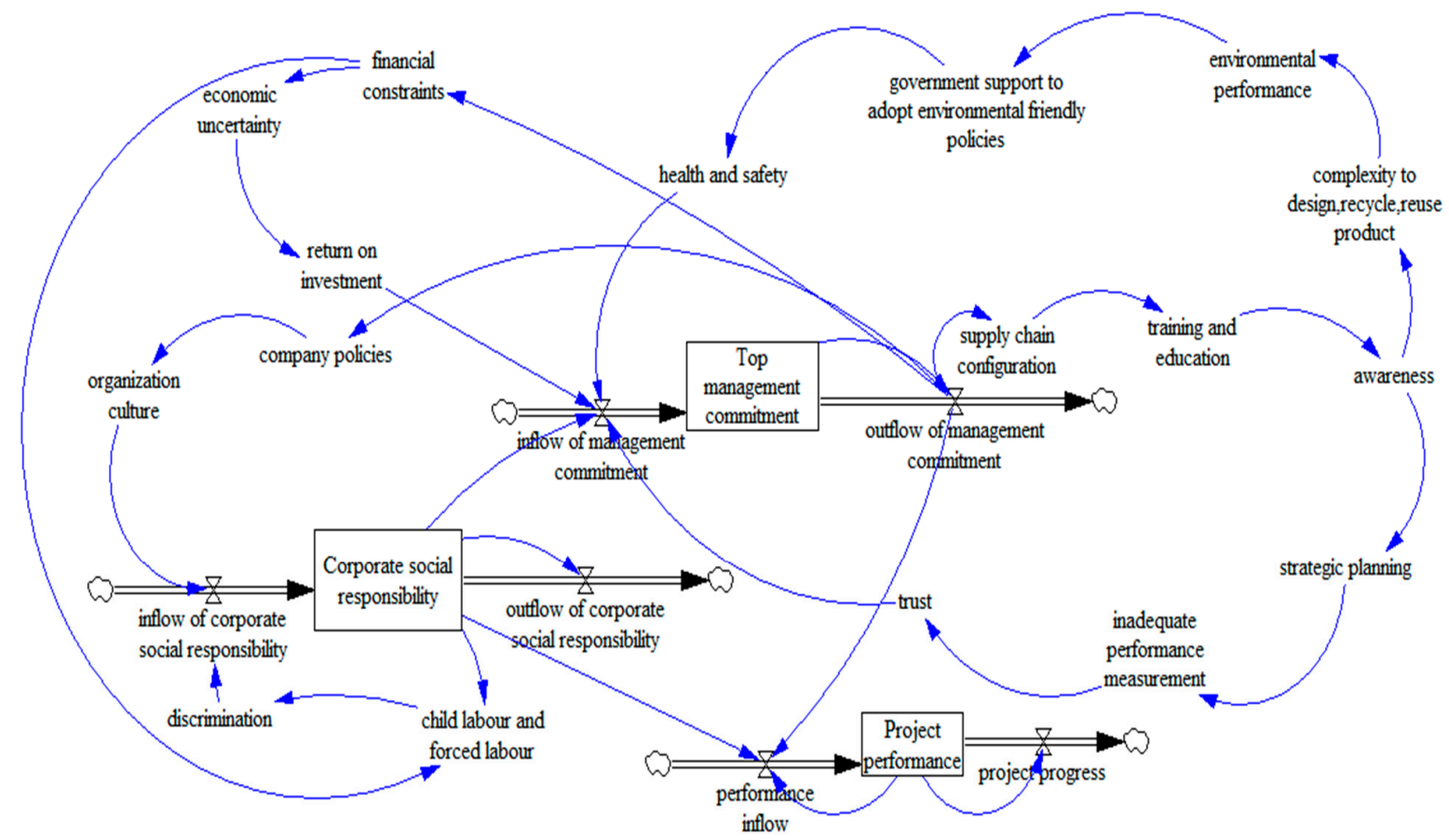

Figure 12. Quantitative SD Model.

\subsection{Simulation Results and Discussion}

The simulation represents the behavior over a time of 5 years. The decrease in the curve of the simulation graph in Figure 13 with time shows how various endogenous variables (such as discrimination, company policies, child labor, forced labor, etc.) affect the corporate social responsibility (which is the company's assurance to responsibly manage the social, environmental, and economic effects of its operations per consumer demands). The presence of these challenges reduces the performance, due to which delays, and cost overruns are seen.

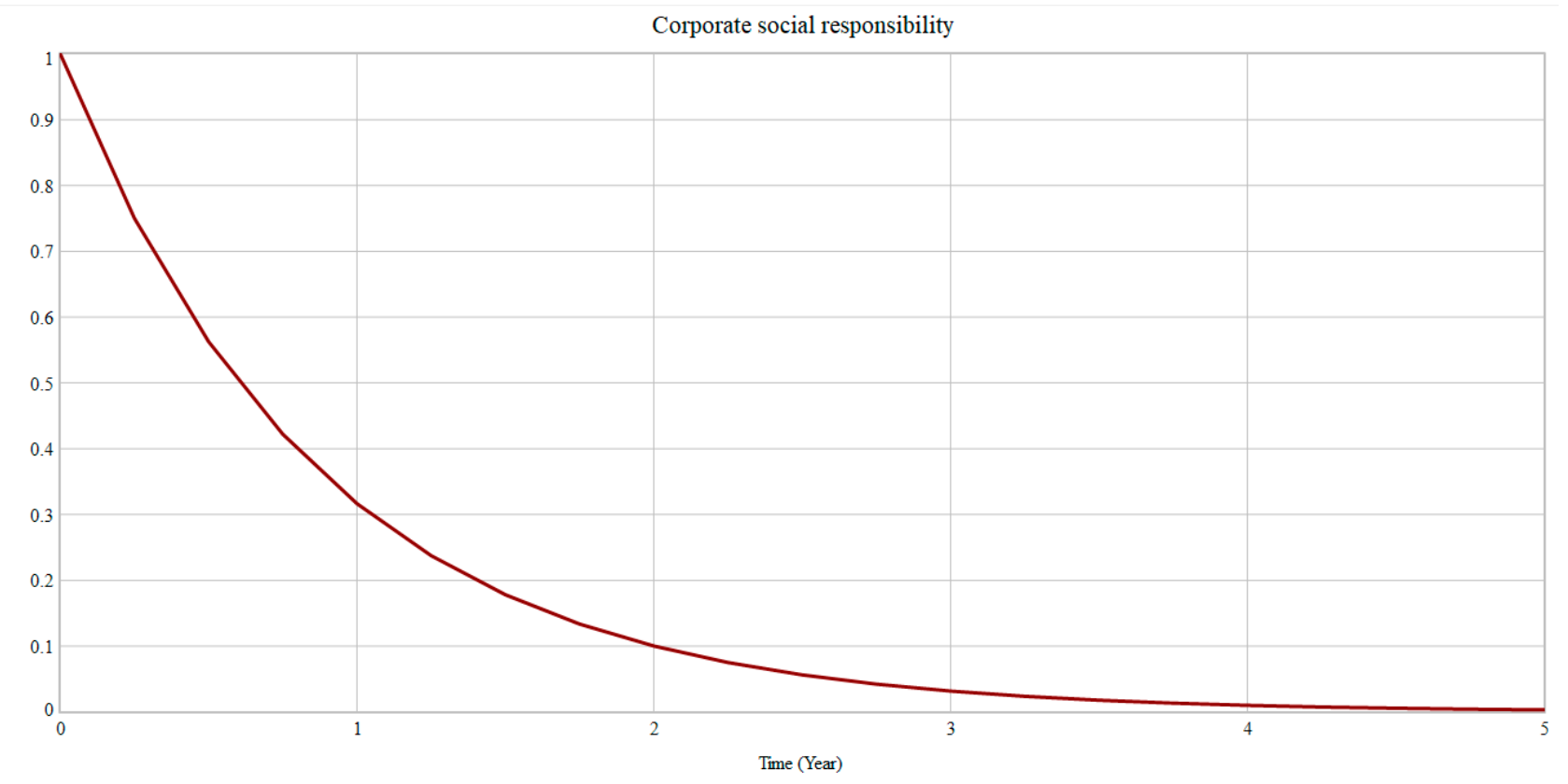

Figure 13. Simulation graph (corporate social responsibility). 
The decrease in the curve of the simulation graph in Figure 14 with time shows how various endogenous variables (such as supply chain configuration, lack of trust, financial constraints, return on investment, etc.) affect the top management commitment, i.e., due to how these variables' different problems, such as lack of communication and coordination, different cost, and time overruns, are seen, which imparts a negative impact on project performance.

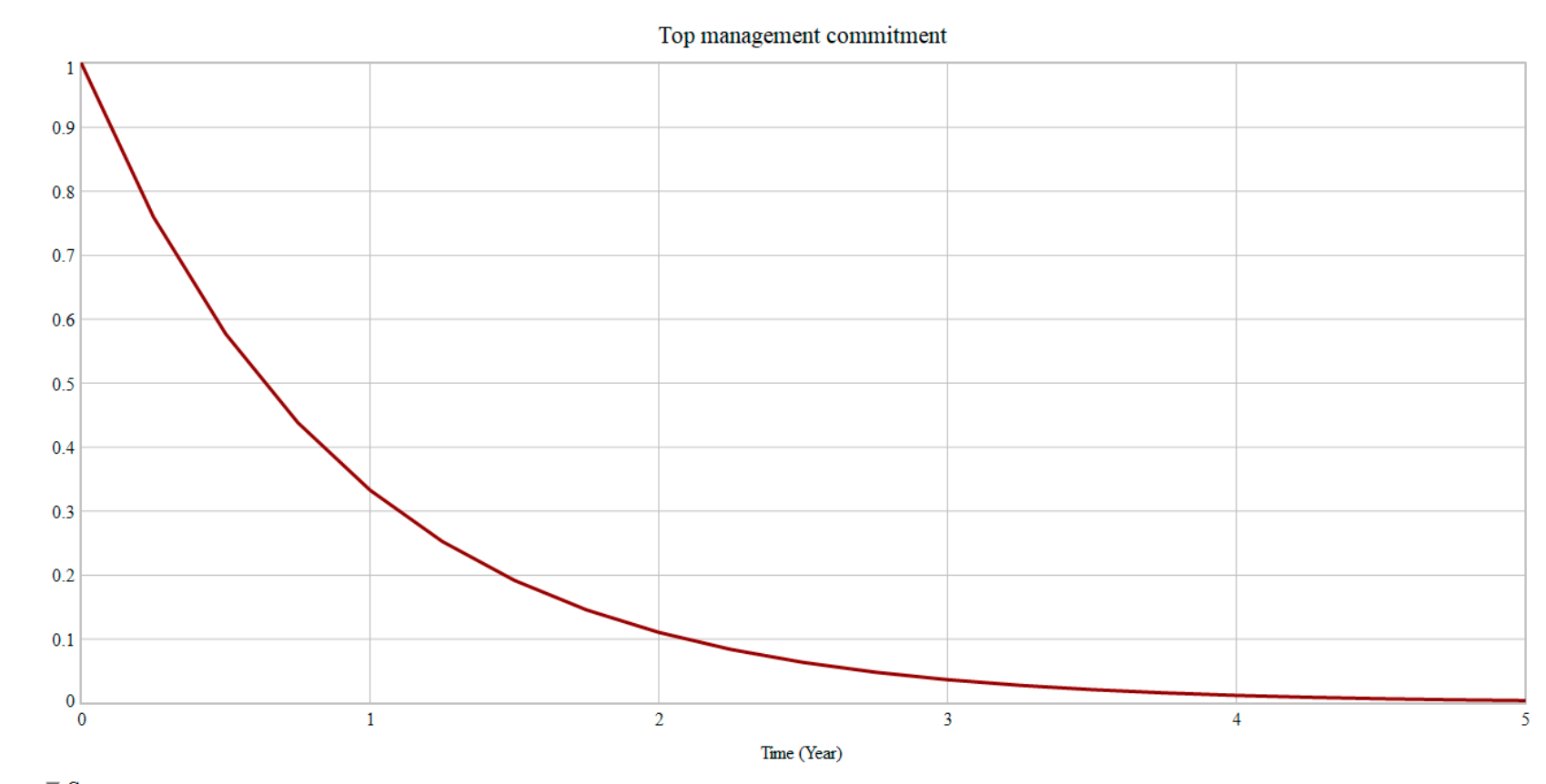

Figure 14. Simulation Graph (top management commitment).

The simulation graph in Figure 15 signifies that due to a decrease in corporate social responsibility and top management commitment, project performance gradually decreases.

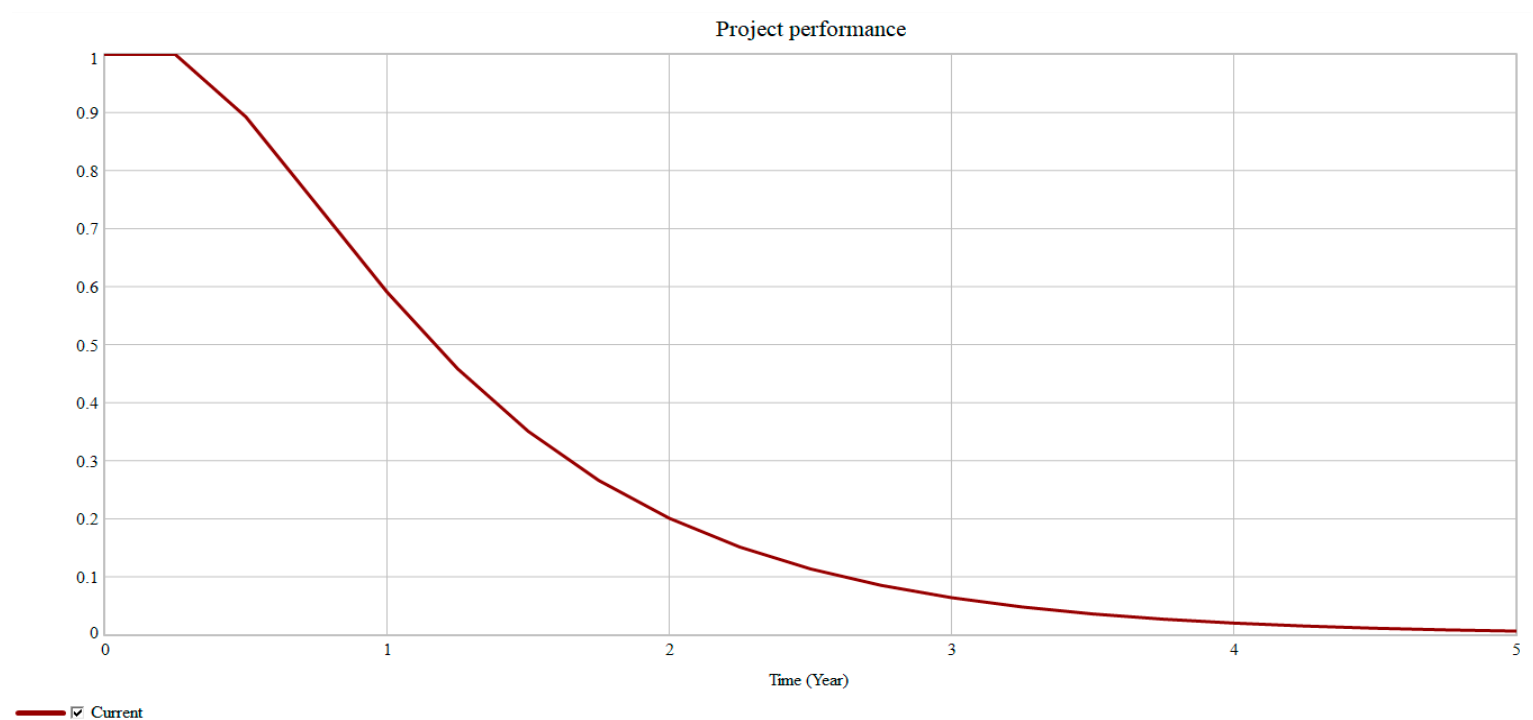

Figure 15. Simulation graph (project performance).

The overall simulation results shown in Figure 16 predict that due to a decrease in corporate social responsibility there would be a decrease in top management commitment, which affects the performance of the project, decreasing gradually until it decreases to a minimum level, i.e., zero. This implies that there is a need to improve numerous 
factors, in particular, corporate social responsibility and top management commitment, which would lead to the adoption of SSCM leading to performance improvement of the CI.

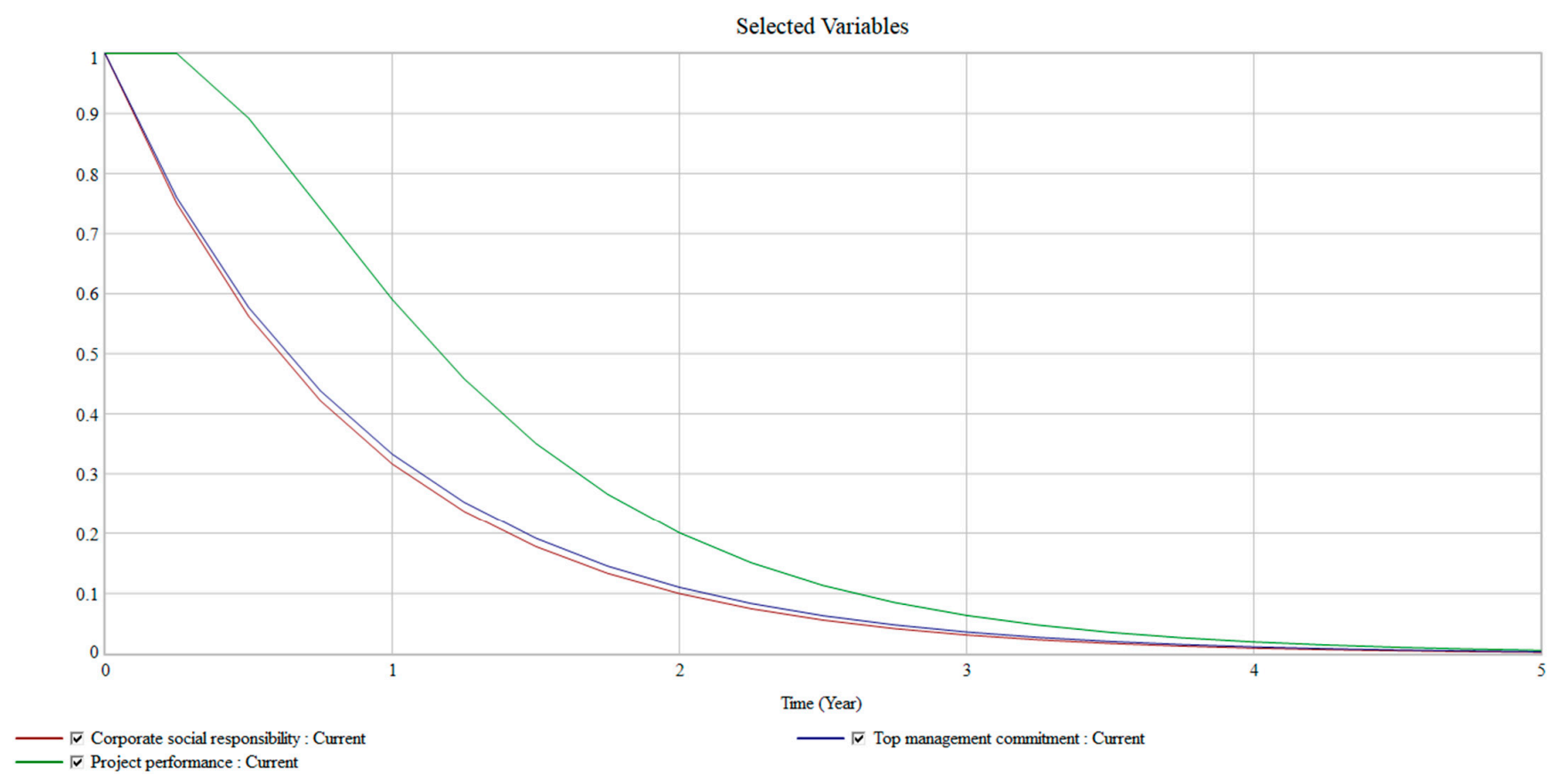

Figure 16. Simulation graph (combined).

\subsection{Model Validation}

An SD model addresses a specific issue rather than a general issue, and the confidence in using the model to help analyze a specific problem should not be based on whether the model can solve other problems [106,107]. In this regard, the model validity depends on the purpose for which the model is developed [102]. The essence of the developed SD model is to help address complexities in the adoption of SSCM in the CI. Therefore, the validation of model structure is the first step of validating the SD model [108]. Qudrat-Ullah and Seong [109] listed the following three tests for checking the structural soundness of an SD model.

\subsubsection{Boundary Adequacy Test}

Sterman [102] articulated the purpose of the boundary adequacy test is to check whether all the core concepts in tackling the issue are endogenous to the model and whether the model's behavior changes substantially when boundary assumptions are relaxed. All the challenges are endogenous, such as supply chain configuration, health, and safety, financial constraints, and discrimination, contributing to SSCM. After analyzing all the variables in the SD model, it is obvious that every single one is important, as all of them have been reported in the literature as causing barriers to SSCM adoption.

\subsubsection{Structure Verification Test}

The objective of the structural verification test is to see whether the model structure matches the descriptive information that was used in the model [110]. The developed CLD is based on variables identified from the literature, and then field professionals are provided with the influencing interrelations amongst all variables. Therefore, the model's structure is realistic and closely reflects the real industry system. So, this is in line with the methodology trialed by Qudrat-Ullah and Seong [109]. 


\subsubsection{Parametric Verification Test}

The mathematical functions developed to link the variables are based on responses from field experts that ensure empirical and theoretical foundations as well as the model verifies parametric verification test. Hence, the model was validated by the aforementioned tests, was validated by taking expert opinions from a total of 12 industry professionals and is in line with the methodology followed by Qudrat-Ullah and Seong [109].

\section{Conclusions and Implications}

SSCM assists the establishment of well-coordinated supply chains by combining economic, economic, and social factors with strategic inter-organizational business processes that efficiently manage content, knowledge, and resources to meet the stakeholders' needs. The nature of the $\mathrm{CI}$ is such that it does not support a coherent supply chain. The supply chain consists of stakeholders such as clients, consultants, and contractors that are mostly working in silos, in particular, the CI of developing countries. There are a lot of issues associated with the supply chain including environmental, social, and economic constraints. There exists a huge challenge, creating complexity, in terms of the adoption of SSCM in the $\mathrm{CI}$, in particular, of developing countries. SD has been adopted to address the complexity in terms of the adoption of SSCM in the CI of developing countries, which has resulted in the development of a CLD and an SD model. The methodology of this study is its novelty, as it is the first research on addressing challenges causing complexity in the adoption of SSCM in the CI.

A total of 82 challenges were extracted from the literature. Data were later collected from the industry on the extracted challenges, to present the industry trends about their perceived criticality in view of various developing countries. After combining the industry and literature scores, using Pareto analysis the top 30 challenges were incorporated into the influence matrix. Out of 95 relationships, field experts confirmed 24 relationships (among 19 challenges), which were then used to develop a CLD depicting a clear picture of interconnections among the identified challenges. The developed CLD comprises IV reinforcing and II balancing loops, which further led to the development of the SD Model. The developed model shows the effect of challenges on "Top Management Commitment" and "Corporate Social Responsibility", which eventually impart an effect on the performance of the project. The simulation results predict that due to the lack of top management commitment and lack of corporate social responsibility, project performance decreased gradually to zero after a certain period. Thus, if top management commitment and corporate social responsibility are addressed, then project performance would improve, as these are the two challenges having most of the interrelationships.

The research findings will help the practitioners to adopt sustainability principles in terms of the supply chain and will not only enhance productivity and performance but also help minimize delays, promote long-term relations, and reduce communication gaps and project complexities. The SD approach is recommended for CI practitioners as it helps to deal with the complexity issues.

No similar work with the current study using system dynamics methodology has been published yet. Therefore, this methodology is the novelty of the study as it is the first study addressing complexity in the adoption of the sustainable supply chain management in the construction industry.

\subsection{Theoretical Contribution}

The study findings provide pragmatic suggestions for improving the $\mathrm{CI}^{\prime}$ s performance. It is the first attempt to study the complexity in the adoption of sustainable supply chain management in the CI. This study has added to the existing literature by identifying the challenges in the adoption of SSCM, bridging the research gap articulated by Galal [10], who suggested that there is a need to address the complexity quantitatively in the adoption of SSCM. 


\subsection{Managerial Contribution}

From the perspective of managers and practitioners, the study findings indicate that that the lack of top management commitment and corporate social responsibility adversely affects project performance. This implies that there is a need to improve numerous factors, in particular, corporate social responsibility and top management commitment that would lead to the adoption of SSCM leading to performance improvement of the CI. The research findings will help the construction industry's practitioners to adopt sustainability principles at all levels in terms of the supply chain and to enhance the productivity and performance of this sector. This will ultimately help minimize delays, promote long-term relationships, and reduce communication gaps and project complexities.

\section{Limitations and Future Research}

The SD approach is recommended for CI practitioners as it helps to deal with complexity issues. Discussing the limitation of the study, one of the limitations is the inclusion of respondents only from developing countries. A further study could be more useful if it involves participants from the developed world. A further study may be directed towards the application of the developed model in the CI. Further research investigating the fourth pillar of sustainability, Culture, will help to develop more understanding among various supply chain stakeholders.

Author Contributions: Conceptualization, M.G. and K.I.A.K.; methodology, M.G.; software, M.G.; writing—original draft preparation, M.G.; writing—review and editing, K.I.A.K., M.J.T., A.R.N. and F.U.; supervision, K.I.A.K. All authors have read and agreed to the published version of the manuscript.

Funding: This research received no external funding.

Institutional Review Board Statement: Not applicable.

Informed Consent Statement: Informed consent was obtained from all respondents involved in the study.

Data Availability Statement: Data are available with the corresponding author and can be shared on reasonable request.

Acknowledgments: The authors would like to concede the assistance and forum provided by the Department of Construction Engineering and Management at the National University of Sciences and Technology in Islamabad, Pakistan. The authors would also like to acknowledge all of the respondents who contributed in data collection.

Conflicts of Interest: The authors declare no conflict of interest.

\section{References}

1. Isa, R.B.; Jimoh, R.A.; Achuenu, E. An overview of the contribution of construction sector to sustainable development in Nigeria. Net J. Bus. Manag. 2013, 1, 1-6.

2. Maqsoom, A.; Charoenngam, C.; Awais, M. Internationalization process of pakistani contractors: An exploratory study. In ICCREM 2013: Construction and Operation in the Context of Sustainability; American Society of Civil Engineer: Reston, VA, USA, 2013; pp. 59-72.

3. Ullah, F.; Thaheem, M.J.; Siddiqui, S.Q.; Khurshid, M.B. Influence of six sigma on project success in construction industry of Pakistan. TQM J. 2017, 29, 276-309. [CrossRef]

4. Sudusinghe, J.I.; Jayaratne, R.P.; Kumarage, A.S. UN SDGs Shaping Sustainable Supply Chains: The Case of Apparel Manufacturers in Developing Countries. In Proceedings of the 2018 IEEE International Conference on Service Operations and Logistics, and Informatics (SOLI), Singapore, 31 July-2 August 2018; pp. 102-107.

5. Yeo, K.; Ning, J. Integrating supply chain and critical chain concepts in engineer-procure-construct (EPC) projects. Int. J. Proj. Manag. 2002, 20, 253-262. [CrossRef]

6. Kerzner, H. Project Management: A Systems Approach to Planning, Scheduling, and Controlling, 12th ed.; John Wiley \& Sons, Inc.: Hoboken, NJ, USA, 2017.

7. Tan, K.C.; Lyman, S.B.; Wisner, J.D. Supply chain management: A strategic perspective. Int. J. Oper. Prod. Manag. 2002, 22, 614-631. 
8. Gimenez, C.; Sierra, V.; Rodon, J. Sustainable operations: Their impact on the triple bottom line. Int. J. Prod. Econ. 2012, 140, 149-159. [CrossRef]

9. Albaloushi, H.; Skitmore, M. Supply chain management in the UAE construction industry. Int. J. Constr. Manag. 2008, 8, 53-71. [CrossRef]

10. Galal, N.; Moneim, A.F.A. Developing sustainable supply chains in developing countries. Procedia CIRP 2016, 48, 419-424. [CrossRef]

11. Koberg, E.; Longoni, A. A systematic review of sustainable supply chain management in global supply chains. J. Clean. Prod. 2019, 207, 1084-1098. [CrossRef]

12. Gopalakrishnan, K.; Yusuf, Y.Y.; Musa, A.; Abubakar, T.; Ambursa, H.M. Sustainable supply chain management: A case study of British Aerospace (BAe) Systems. Int. J. Prod. Econ. 2012, 140, 193-203. [CrossRef]

13. Govindan, K.; Kaliyan, K.M.; Kannan, D.; Haq, A. Barriers analysis for green supply chain management implementation in Indian industries using analytic hierarchy process. Int. J. Prod. Econ. 2014, 147, 555-568. [CrossRef]

14. Christopher, M. Logistics E Supply Chain Management; Pearson: London, UK, 2016.

15. De Angelis, R.; Howard, M.; Miemczyk, J. Supply chain management and the circular economy: Towards the circular supply chain. Prod. Plan. Control. 2018, 29, 425-437. [CrossRef]

16. Naderpour, A.; Sardroud, J.M.; Mofid, M.; Xenidis, Y.; Pour Rostam, T. Uncertainty management in time estimation of construction projects: A systematic literature review and new model development. Sci. Iran. 2017, 26, 752-778. [CrossRef]

17. Limsila, K.; Ogunlana, S.O. Performance and leadership outcome correlates of leadership styles and subordinate commitment. Eng. Constr. Arch. Manag. 2008, 15, 164-184. [CrossRef]

18. Martens, M.L.; Carvalho, M.M. Key factors of sustainability in project management context: A survey exploring the project managers' perspective. Int. J. Proj. Manag. 2017, 35, 1084-1102. [CrossRef]

19. Hubbard, G. Measuring organizational performance: Beyond the triple bottom line. Bus. Strat. Environ. 2009, 18, 177-191. [CrossRef]

20. Onat, N.C.; Kucukvar, M.; Tatari, O. Integrating triple bottom line input-output analysis into life cycle sustainability assessment framework: The case for US buildings. Int. J. Life Cycle Assess. 2014, 19, 1488-1505. [CrossRef]

21. Ramaswamy, M. Leveraging information technology to create sustainable supply chains. Issues Inf. Syst. 2017, $18,95-102$.

22. Redclift, M. Sustainable development (1987-2005): An oxymoron comes of age. Sustain. Dev. 2005, 13, 212-227. [CrossRef]

23. Segerstedt, A.; Olofsson, T. Supply chains in the construction industry. Supply Chain Manag. Int. J. 2010, 15, 347-353. [CrossRef]

24. Boström, M. A missing pillar? Challenges in theorizing and practicing social sustainability: Introduction to the special issue. Sustain. Sci. Pr. Policy 2012, 8, 3-14. [CrossRef]

25. Al Zaabi, S.; Al Dhaheri, N.; Diabat, A. Analysis of interaction between the barriers for the implementation of sustainable supply chain management. Int. J. Adv. Manuf. Technol. 2013, 68, 895-905. [CrossRef]

26. Dixit, S.; Mandal, S.N.; Sawhney, A.; Singh, S. Area of linkage between lean construction and sustainability in Indian construction industry. Int. J. Civ. Eng. Technol. 2017, 8, 623-636.

27. Diabat, A.; Govindan, K. An analysis of the drivers affecting the implementation of green supply chain management. Resour. Conserv. Recycl. 2011, 55, 659-667. [CrossRef]

28. Zuo, J.; Jin, X.-H.; Flynn, L. Social sustainability in construction-An explorative study. Int. J. Constr. Manag. 2012, 12, 51-63. [CrossRef]

29. Rogers, S.H.; Gardner, K.H.; Carlson, C.H. Social Capital and Walkability as Social Aspects of Sustainability. Sustainability 2013, 5, 3473-3483. [CrossRef]

30. Morais, D.O.; Silvestre, B.S. Advancing social sustainability in supply chain management: Lessons from multiple case studies in an emerging economy. J. Clean. Prod. 2018, 199, 222-235. [CrossRef]

31. Qorri, A.; Mujkić, Z.; Kraslawski, A. A conceptual framework for measuring sustainability performance of supply chains. J. Clean. Prod. 2018, 189, 570-584. [CrossRef]

32. Ahi, P.; Searcy, C. A comparative literature analysis of definitions for green and sustainable supply chain management. J. Clean Prod. 2013, 52, 329-341. [CrossRef]

33. Kulkarni, A.; Halder, S. A simulation-based decision-making framework for construction supply chain management (SCM). Asian J. Civ. Eng. 2019, 21, 229-241. [CrossRef]

34. Bal, M.; Bryde, D.; Fearon, D.; Ochieng, E. Stakeholder engagement: Achieving sustainability in the construction sector. Sustainability 2013, 5, 695-710. [CrossRef]

35. McBeath, B.; Nissen, L.; Goodluck, C.; Brennan, E.M. The intersection of disparity reduction and social sustainability. In Social Sustainability: A Multilevel Approach to Social Inclusion; Routledge: Oxfordshire, UK, 2013; p. 126.

36. Wheeler, S.M. Planning for Sustainability: Creating Livable, Equitable and Ecological Communities; Routledge: Oxfordshire, UK, 2013.

37. Seuring, S.; Müller, M. From a literature review to a conceptual framework for sustainable supply chain management. J. Clean. Prod. 2008, 16, 1699-1710. [CrossRef]

38. Wang, Y.; Han, Q.; De Vries, B.; Zuo, J. How The Public Reacts To Social Impacts In Construction Projects? A Structural Equation Modeling Study. Int. J. Proj. Manag. 2016, 34, 1433-1448. [CrossRef]

39. Bell, S.; Morse, S. Sustainability Indicators: Measuring the Immeasurable? Routledge: Oxfordshire, UK, 2012. 
40. Sapiri, H.; Hew, J.Z.; Ahmad, N.; Abidin, N.Z.; Hawari, N.N. Introduction to System Dynamic Modelling and Vensim Software; UUM Press: Kedah, Malaysia, 2017.

41. Khan, K.I.A.; Flanagan, R.; Lu, S.-L. Managing information complexity using system dynamics on construction projects. Constr. Manag. Econ. 2016, 34, 192-204. [CrossRef]

42. Melkonyan, A.; Krumme, K.; Gruchmann, T.; Spinler, S.; Schumacher, T.; Bleischwitz, R. Scenario and strategy planning for transformative supply chains within a sustainable economy. J. Clean. Prod. 2019, 231, 144-160. [CrossRef]

43. Khan, S.A.R.; Yu, Z.; Golpîra, H.; Sharif, A.; Mardani, A. A state-of-the-art review and meta-analysis on sustainable supply chain management: Future research directions. J. Clean. Prod. 2020, 278, 123357. [CrossRef]

44. Crompton, L. A Standardised Incorporated Partnering Model for the UK Construction Industry; University of Central Lancashire: Preston, UK, 2016.

45. Papadopoulos, G.A.; Zamer, N.; Gayialis, S.P.; Tatsiopoulos, I.P. Supply Chain Improvement in Construction Industry. Univers. J. Manag. 2016, 4, 528-534. [CrossRef]

46. Mentzer, J.T.; DeWitt, W.; Keebler, J.S.; Min, S.; Nix, N.W.; Smith, C.D.; Zacharia, Z.G. Defining supply chain management. J. Bus. Logist. 2001, 22, 1-25. [CrossRef]

47. Stevenson, M.; Spring, M. Flexibility from a supply chain perspective: Definition and review. Int. J. Oper. Prod. Manag. 2007, 27, 685-713. [CrossRef]

48. Abbasi, M.; Nilsson, F. Themes and challenges in making supply chains environmentally sustainable. Supply Chain Manag. Int. J. 2012, 17, 517-530. [CrossRef]

49. Ashby, A.L.; Leat, M.; Smith, M. Making connections: A review of supply chain management and sustainability literature. Supply Chain Manag. Int. J. 2012, 17, 497-516. [CrossRef]

50. Ballou, R.H. Business Logistics/Supply Chain Management; 5/E (With Cd); Pearson Education India: Noida, India, 2007.

51. Jadhav, A.; Orr, S.; Malik, M. The role of supply chain orientation in achieving supply chain sustainability. Int. J. Prod. Econ. 2019, 217, 112-125. [CrossRef]

52. Laeequddin, M.; Sahay, B.; Sahay, V.; Waheed, K.A. Measuring trust in supply chain partners' relationships. Meas. Bus. Excel. 2010, 14, 53-69. [CrossRef]

53. Kusi-Sarpong, S.; Gupta, H.; Sarkis, J. A supply chain sustainability innovation framework and evaluation methodology. Int. J. Prod. Res. 2019, 57, 1990-2008. [CrossRef]

54. Saavedra, M.M.R.; Fontes, C.H.d.O.; Freires, F.G.M. Sustainable and renewable energy supply chain: A system dynamics overview. Renew. Sustain. Energy Rev. 2018, 82, 247-259. [CrossRef]

55. Martins, C.; Pato, M. Supply chain sustainability: A tertiary literature review. J. Clean. Prod. 2019, 225, 995-1016. [CrossRef]

56. Elmualim, A.; Shockley, D.; Valle, R.; Ludlow, G.; Shah, S. Barriers and commitment of facilities management profession to the sustainability agenda. Build. Environ. 2010, 45, 58-64. [CrossRef]

57. Chan, A.P.C.; Darko, A.; Olanipekun, A.O.; Ameyaw, E.E. Critical barriers to green building technologies adoption in developing countries: The case of Ghana. J. Clean. Prod. 2018, 172, 1067-1079. [CrossRef]

58. das Neves, J.G.; Duarte, A.P.; Simões, E.; Santos, M.J. Theoretical contributions towards rethinking corporate social responsibility. Manag. Res. J. Iberoam. Acad. Manag. 2014, 12, 288-307.

59. Kaveh, A.; Vazirinia, Y. Optimization of Tower Crane Location and Material Quantity between Supply and Demand Points: A Comparative Study. Period. Polytech. Civ. Eng. 2018, 62, 732-745. [CrossRef]

60. Lindgreen, A.; Swaen, V.; Maon, F.; Andersen, M.; Skjoett-Larsen, T. Corporate social responsibility in global supply chains. Supply Chain. Manag. Int. J. 2009, 161, 161-172.

61. Saberi, S.; Kouhizadeh, M.; Sarkis, J.; Shen, L. Blockchain technology and its relationships to sustainable supply chain management. Int. J. Prod. Res. 2019, 57, 2117-2135. [CrossRef]

62. Brandenburg, M.; Govindan, K.; Sarkis, J.; Seuring, S. Quantitative models for sustainable supply chain management: Developments and directions. Eur. J. Oper. Res. 2014, 233, 299-312. [CrossRef]

63. Faisal, M.N. Sustainable supply chains: A study of interaction among the enablers. Bus. Process. Manag. J. 2010, 16, 508-529. [CrossRef]

64. Adetunji, I.; Price, A.D.F.; Fleming, P. Achieving sustainability in the construction supply chain. In Proceedings of the Institution of Civil Engineers-Engineering Sustainability; Thomas Telford Ltd.: London, UK, 2008; Volume 161, pp. 161-172.

65. Ageron, B.; Gunasekaran, A.; Spalanzani, A. Sustainable supply management: An empirical study. Int. J. Prod. Econ. 2012, 140, 168-182. [CrossRef]

66. Jakhar, S.K.; Rathore, H.; Mangla, S.K. Is lean synergistic with sustainable supply chain? An empirical investigation from emerging economy. Resour. Conserv. Recycl. 2018, 139, 262-269. [CrossRef]

67. Utting, P. Business Responsibility for Sustainable Development; Geneva 2000 Occasional Paper; UN Research Institute for Social Development Geneva: Geneva, Switzerland, 2000.

68. Jamali, D.; Karam, C. Corporate Social Responsibility in Developing Countries as an Emerging Field of Study. Int. J. Manag. Rev. 2016, 20, 32-61. [CrossRef]

69. Mani, V.; Gunasekaran, A.; Delgado, C. Supply chain social sustainability: Standard adoption practices in Portuguese manufacturing firms. Int. J. Prod. Econ. 2018, 198, 149-164. [CrossRef] 
70. Lehtonen, M. The environmental?-Social interface of sustainable development: Capabilities, social capital, institutions. Ecol. Econ. 2004, 49, 199-214. [CrossRef]

71. Sedereviciute, K.; Valentini, C. Towards a More Holistic Stakeholder Analysis Approach. Mapping Known and Undiscovered Stakeholders from Social Media. Int. J. Strat. Commun. 2011, 5, 221-239. [CrossRef]

72. Wong, J.K.W.; Chan, J.K.S.; Wadu, M.J. Facilitating effective green procurement in construction projects: An empirical study of the enablers. J. Clean. Prod. 2016, 135, 859-871. [CrossRef]

73. Farooqui, R.; Ahmed, S.; Lodi, S. Assessment of pakistani construction industry-current performance and the way forward. J. Adv. Perform. Inf. Value 2008, 1, 51. [CrossRef]

74. Hassini, E.; Surti, C.; Searcy, C. A literature review and a case study of sustainable supply chains with a focus on metrics. Int. J. Prod. Econ. 2012, 140, 69-82. [CrossRef]

75. Weingaertner, C.; Moberg, A. Åsa Exploring Social Sustainability: Learning from Perspectives on Urban Development and Companies and Products. Sustain. Dev. 2014, 22, 122-133. [CrossRef]

76. Thompson, B.P.; Bank, L.C. Use of system dynamics as a decision-making tool in building design and operation. Build. Environ. 2010, 45, 1006-1015. [CrossRef]

77. Xu, Z.; Coors, V. Combining system dynamics model, GIS and 3D visualization in sustainability assessment of urban residential development. Build. Environ. 2012, 47, 272-287. [CrossRef]

78. Rasul, N.; Malik, M.S.A.; Bakhtawar, B.; Thaheem, M.J. Risk assessment of fast-track projects: A systems-based approach. Int. J. Constr. Manag. 2021, 21, 1099-1114. [CrossRef]

79. Walker, H.; Brammer, S. Sustainable procurement in the United Kingdom public sector. Supply Chain Manag. Int. J. 2009, 14, 128-137. [CrossRef]

80. Ravi, V.; Shankar, R. Analysis of interactions among the barriers of reverse logistics. Technol. Forecast. Soc. Chang. 2005, 72, 1011-1029. [CrossRef]

81. Akintoye, A.; McIntosh, G.; Fitzgerald, E. A survey of supply chain collaboration and management in the UK construction industry. Eur. J. Purch. Supply Manag. 2000, 6, 159-168. [CrossRef]

82. Dainty, A.R.; Millett, S.J.; Briscoe, G.H. New perspectives on construction supply chain integration. Supply Chain Manag. Int. J. 2001, 6, 163-173. [CrossRef]

83. Walker, H.; Di Sisto, L.; McBain, D. Drivers and barriers to environmental supply chain management practices: Lessons from the public and private sectors. J. Purch. Supply Manag. 2008, 14, 69-85. [CrossRef]

84. Wognum, P.N.; Bremmers, H.; Trienekens, J.H.; van der Vorst, J.G.; Bloemhof, J. Systems for sustainability and transparency of food supply chains-current status and challenges. Adv. Eng. Informatics 2011, 25, 65-76. [CrossRef]

85. de Brito, M.P.; Carbone, V.; Blanquart, C.M. Towards a sustainable fashion retail supply chain in Europe: Organisation and performance. Int. J. Prod. Econ. 2008, 114, 534-553. [CrossRef]

86. Negi, M.; Ahuja, V.; Baruah, P. Sustainable supply chain management in indian construction industry. In Proceedings of the National Conference on Sustainable Supply Chain Management an Indian Perspective (CRIMM), West Bengal, India, 10 March 2017.

87. Keating, B.; Quazi, A.; Kriz, A.; Coltman, T. In pursuit of a sustainable supply chain: Insights from Westpac Banking Corporation. Supply Chain Manag. Int. J. 2008, 13, 175-179. [CrossRef]

88. Svensson, G. Aspects of sustainable supply chain management (SSCM): Conceptual framework and empirical example. Supply Chain Manag. Int. J. 2007, 12, 262-266. [CrossRef]

89. Swee, S.K.; Sev, V.N.; Amer, Y. Challenges in implementing sustainable supply chain within a collaborative manufacturing network. In Proceedings of the 2010 8th International Conference on Supply Chain Management and Information, Hong Kong, China, 6-9 October 2010; IEEE: Piscataway, NJ, USA, 2010.

90. Walker, H.; Jones, N. Sustainable supply chain management across the UK private sector. Supply Chain Manag. Int. J. 2012, 17, 15-28. [CrossRef]

91. Ahmad, N.K.W.; De Brito, M.P.; Rezaei, J.; Tavasszy, L.A. An integrative framework for sustainable supply chain management practices in the oil and gas industry. J. Environ. Plan. Manag. 2016, 60, 577-601. [CrossRef]

92. Giunipero, L.C.; Hooker, R.E.; Denslow, D. Purchasing and supply management sustainability: Drivers and barriers. J. Purch. Supply Manag. 2012, 18, 258-269. [CrossRef]

93. Seuring, S.; Müller, M. Core issues in sustainable supply chain management-A Delphi study. Bus. Strategy Environ. 2008, 17, 455-466. [CrossRef]

94. Beske, P. Dynamic capabilities and sustainable supply chain management. Int. J. Phys. Distrib. Logist. Manag. 2012, $42,372-387$. [CrossRef]

95. Beske, P.; Seuring, S. Putting sustainability into supply chain management. Supply Chain Manag. Int. J. 2014, 19, 322-331. [CrossRef]

96. Ojo, E.; Mbowa, C.; Akinlabi, E.T. Barriers in implementing green supply chain management in construction industry. In Proceedings of the 2014 International Conference on Industrial Engineering and Operations Management, Bali, India, 7-9 January 2014.

97. Ahmad, Z.; Thaheem, M.J.; Maqsoom, A. Building information modeling as a risk transformer: An evolutionary insight into the project uncertainty. Autom. Constr. 2018, 92, 103-119. [CrossRef] 
98. Wang, Y.; Yin, W.; Zeng, J. Global Convergence of ADMM in Nonconvex Nonsmooth Optimization. J. Sci. Comput. $2019,78,29-63$. [CrossRef]

99. Nguyen, N.C.; Bosch, O.J.H. A Systems Thinking Approach to identify Leverage Points for Sustainability: A Case Study in the Cat Ba Biosphere Reserve, Vietnam. Syst. Res. Behav. Sci. 2013, 30, 104-115. [CrossRef]

100. Loehlin, J.C.; Beaujean, A.A. Latent Variable Models: An Introduction to Factor, Path, and Structural Equation Analysis; Taylor \& Francis: Oxford, UK, 2016.

101. Sterman, J.D. Business Dynamics: Systems Thinking and Modeling for a Complex World; Massachusetts Institute of Technology: Cambridge, MA, USA, 2002.

102. Sterman, J. Business Dynamics; Irwin/McGraw-Hill: New York, NY, USA, 2000.

103. Richardson, G.P. Reflections on the foundations of system dynamics. Syst. Dyn. Rev. 2011, 27, 219-243. [CrossRef]

104. Ullah, W.; Noor, S.; Tariq, A. The development of a basic framework for the sustainability of residential buildings in Pakistan. Sustain. Cities Soc. 2018, 40, 365-371. [CrossRef]

105. Al-Kofahi, Z.G.; Mahdavian, A.; Oloufa, A. System dynamics modeling approach to quantify change orders impact on labor productivity 1: Principles and model development comparative study. Int. J. Constr. Manag. 2020, 1-12. [CrossRef]

106. Richardson, G.P.; Pugh, L.A. Introduction to system dynamics modeling with DYNAMO. J. Oper. Res. Society 1997, $48,1146$. [CrossRef]

107. Harrell, F.E., Jr. Regression Modeling Strategies: With Applications to Linear Models, Logistic and Ordinal Regression, and Survival Analysis; Springer: New York, NY, USA, 2015.

108. Barlas, Y. Formal aspects of model validity and validation in system dynamics. Syst. Dyn. Rev. J. Syst. Dyn. Soc. 1996, 12, 183-210. [CrossRef]

109. Qudrat-Ullah, H.; Seong, B.S. How to do structural validity of a system dynamics type simulation model: The case of an energy policy model. Energy Policy 2010, 38, 2216-2224. [CrossRef]

110. Nylund, K.L.; Asparouhov, T.; Muthén, B.O. Deciding on the Number of Classes in Latent Class Analysis and Growth Mixture Modeling: A Monte Carlo Simulation Study. Struct. Equ. Model. A Multidiscip. J. 2007, 14, 535-569. [CrossRef] 